\title{
Nimetamiskonstruktsioonid eesti murretes: murdeerinevused või suuline süntaks? ${ }^{1}$
}

\author{
Liina Lindström \\ Tartu Ülikooli eesti ja üldkeeleteaduse instituudi \\ eesti keele dotsent, eesti keele vanemteadur \\ liina.lindstrom@ut.ee \\ Maarja-Liisa Pilvik \\ Tartu Ülikooli eesti ja üldkeeleteaduse instituudi \\ doktorant, rakendusliku dialektoloogia nooremteadur \\ maarja-liisa.pilvik@ut.ee \\ Helen Plado \\ Tartu Ülikooli eesti ja üldkeeleteaduse instituudi \\ eesti keele lektor, eesti keele teadur, \\ Võru Instituudi teadur \\ helen.plado@ut.ee
}

Teesid: Artiklis vaadeldakse nimetamiskonstruktsioone (NK), mis väljendavad, kuidas objektina realiseeruvat argumenti kutsutakse. NK koosneb nimetamist väljendavast verbist umbisikulises tegumoes, objektist, mida kuidagi nimetatakse, ning verbi komplemendist, mis annab edasi, kuidas objekti nimetatakse. Artiklis vaadeldakse NK-sisest varieerumist eesti murretes, kasutades selleks eesti murrete korpuse andmestikku. Eesmärk on selgitada välja, milline osa varieerumisest sõltub murdealast, mis aga muudest teguritest. Andmeid on analüüsitud kvantitatiivselt, rakendades klassifitseerimispuude ja korrespondentsanalüüsi meetodeid. Analüüsist selgub, et enim on murdest mõjutatud verbi valik. Murre selgitab küllalt palju ka objekti käände varieerumist: läänepoolsed murded kasutavad konstruktsioonis nimetavat käänet enam kui idapoolsed. Komplemendi kääne on aga mõjutatud peamiselt objekti käändest. Üldiselt domineerib andmestikus nimetavas käändes komplemendi kasutus, mida võib seostada tekstide suulisusega ning suulises kõnes sageli toimuva tsiteerimisega, mis tingib komplemendi nõrga integreerituse argumentstruktuuri.

Märksõnad: eesti murded, murdesüntaks, nimetamiskonstruktsioon, suuline süntaks, varieerumine 


\section{Sissejuhatus}

Murdekeel on Eestis kasutusel olnud eelkõige suulise keelevormina, vastandudes tänapäeva kirjakeelele nii suhtluskanali kui ka piirkondlike eripärade poolest. Murdekeelt analüüsides on seetõttu sageli ebaselge, kust jookseb piir teatud murdele iseloomulike joonte ja üldisest suulisest suhtluskanalist tulenevate erijoonte vahel. Ka õpikus "Eesti murded ja kohanimed" on niigi napp murrete süntaksi käsitlus jagatud kaheks: üks osa käsitleb murret kui suulist keelt, teine osa neid jooni, mis ei ole seotud suulisusega ning on pigem "päris" murretevahelised erinevused. (Pajusalu et al. 2009: 107-115.) Esimese rühma erinevusi võib pidada universaalseteks ja ühiseks tänapäeva eesti keele suulise kasutusega (vt nt Hennoste 2000-2001; Lindström 2005; Hennoste 2013; Amon 2015 jpt). Teise rühmaga ehk eesti murrete süntaktiliste erinevustega on tegeldud vähem, viimastel aastatel peamiselt projekti "Eesti murrete süntaks" raames (vt nt Uiboaed 2013; Uiboaed et al. 2013; Lindström et al. 2014; Plado 2015; Klavan et al. 2015; Lindström et al. 2015; Lindström et al., ilmumas, Pilvik 2016), ent loomulikult on see vaid jäämäe tipp: eesti murrete varieeruvus on sedavõrd suur, et uurimisainest jätkub kauaks.

Keerukaks läheb siis, kui on väga raske öelda, kas tegu on suulisusest tingitud joontega või murdeerinevustega. Murdekeel, millel puudub kirjakeele traditsioon, võib olla kinnistanud lausestruktuure, mida me praeguse eesti kirjakeele põhjal analüüsiksime pigem suulisusest tingitud "veaks", ent nende kasutamine murdes on sedavõrd süstemaatiline, et see võib olla ka hoopis teatud murdele iseloomulik joon. Selliseid näiteid leiab murdetekstides palju. Näiteks võib tuua alistavate sidendite paiknemise kaugemal kui vahetult osalause alguses $\left(1-3^{2}\right)$. Kirjakeeles paikneb alistav sidend alati vahetult osalause algul, ent murdetekstides ei ole see alati nii.

maq ku mõtsa+vah'ihh ol'l'i (Seto, Ida-Seto)

Mere tuul kui oli ja puud kohisesivad, siis täma ei saand maka (Ranna, Hlj, Must 1987: 299)

Süda valutas poegide pärast, merel kes olivad

(Ranna, Hlj, Must 1987: 299)

Nähtust on mainitud kirderannikumurretele iseloomuliku süntaktilise erijoonena Mari Musta raamatus "Kirderannikumurre" (Must 1987: 299), ent nagu näeme Ida-Seto näitest (1), ei ole see iseloomulik vaid kirderanniku murderühmale. Nende näidete puhul võib küsida, kas tegemist on suulisusest tingitud sõnajärjeveaga, murdejoonega või hoopis mingi varasema süntaktilise struktuuri (mis muidugi on suulise keele süntaks) jäänukiga murdekeeles. 
Sarnaseid näiteid, kus pole selge, kas tegemist on suulise kõne eripära, keelevea või murdejoonega, võib leida veelgi. Näiteks ei ole mine-nominalisatsioonides objekt alati omandanud (kirjakeele seisukohalt) ootuspärast omastava käände vormi, vaid püsib osastavas käändes (4-5) (vt Pilvik 2016, 2017). Tänapäeva kirjakeele seisukohalt vaadatuna on see viga, ent see võib kajastada ka varasemat vähem grammatiseerunud/kinnistunud keelekuju, mis on edasi elanud just suulises keelekasutuses.

$$
\begin{aligned}
& s=\text { olli ta ommukkuss kõva ja ess ole tedä (.) `keitmist (Mulgi, Hel) } \\
& \text { 'siis oli ta hommikuks kõva ei ja ei olnud tema köitmist' } \\
& \text { *enne *koittu oli (.) vedamine neid *välja (Ranna, Jõe) } \\
& \text { 'enne koitu oli nende väljavedamine' }
\end{aligned}
$$

Ühelt poolt tundub, et kõnelejad ei käsitle eespool kirjeldatud keelelisi struktuure keeleveana (ei tõtta parandama) ning tegu tundub olevat kinnistunud konstruktsioonimalliga. Teiselt poolt on vähemalt mine-nominalisatsioonide puhul raske öelda midagi selle kohta, kas sellised kasutusjuhud on iseloomulikud mingile teatud piirkonnale või mitte - nähtus on piisavalt sage selleks, et seda mitte eirata, ent siiski liiga harv, et midagi öelda leviku kohta (vt Pilvik 2016).

Üks juhtumeid, kus pole selge, kas tegu on suulise keelekasutuse eripäraga, murdejoonega või millegi muuga, tuleb vaatluse alla ka käesolevas artiklis. Vaatleme eesti murrete korpuse andmetele tuginedes konstruktsiooni, mida nimetame nimetamiskonstruktsiooniks. Nimetamiskonstruktsiooniga väljendatakse seda, kuidas objektina realiseeruvat argumenti kutsutakse.

Nimetamiskonstruktsioon koosneb nimetamist tähistavast predikaadist (impersonaalivormis) ning kahest argumendist: objektist, mida kuidagi nimetatakse, ja komplemendist ehk verbi seotud laiendist, milleks/missuguseks objekti

\begin{tabular}{|c|c|}
\hline sedä & kutsutti \\
\hline OBJ & $\mathrm{V}$ \\
\hline
\end{tabular}
kutsutakse. Kirjakeelest lähtuvalt võib konstruktsiooni struktuuriks pidada $\mathrm{Obj}_{\text {prt }}+\mathrm{V}_{\text {imps }}+\mathrm{Kompl}_{\text {trnsl }}$, mida väljendab näiteks ka murdekeelne lause (6).

Näites 6 on kirjakeelest erinev peamiselt saava käände lõpp -st, mis on iseloomulik kogu Eesti idapoolsele osale Setumaast Alutaguseni, ent muidu järgib näide kirjakeele malli: objekt on osastavas käändes ning komplement on saavas käändes. Kui vaatame aga muid sarnaseid lauseid, näeme, et murdetekstides on palju varieeruvust: objekti kääne võib olla ka nimetav $(7,10)$ või puudub objekt lausest hoopiski (9); komplement võib olla nimetavas käändes (7-8) ja/ või seotud sidendiga et (9). Vahel võib komplement ka konstruktsioonist välja jääda. See juhtub enamasti siis, kui keelejuht ei suuda terminit meenutada 
või parandab end, minnes üle mõnele muule konstruktsioonile (10). Komplemendi väljajättu võib nimetamiskonstruktsiooni puhul pidada seega ehk enim suulisusest tingitud nähtuseks.

ning igast puust 'tehti neid 'väiksid `pappu (...) nee [OBJ, n] kutsutti $=$ sis kippud [KOMPL, n] 'ikke (Saarte, Ans) ja siis seda [OBJ, p] ‘ kutsutti obaduse auk [KOMPL, n] (Alutaguse, Iis)

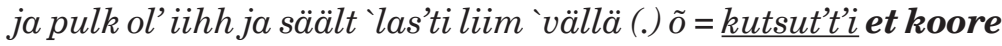
kä̈'n' [KOMPL, n] (Võru, Rõu)

se on kimbu väät (...) see on köva (.) see [OBJ, n] $\underline{\text { kutsuttasse }}$ nüid (.) see on kaa (.) väädid (...) (Saarte, Pha)

Samas ei ole objekti ega harvem ka komplemendi väljendamata jätmises midagi erandlikku. On üldine universaalne suhtlusprintsiip, et ennustatavat infot pole tarvis eraldi välja tuua (Givón 2017: 3). See ilmneb eesti keeles argumentide väljajätus laiemalt: diskursuses aktiivsed, s.t tuntud referendid jäetakse sageli lauses eksplitseerimata. Eriti sageli jäetakse eksplitseerimata subjekti rollis olevad argumendid, sest need on kõige tüüpilisemalt diskursusest tuntud (vt nt Metslang 2014: 232-238; eesti murrete 1. isiku subjektpronoomeni väljajätu kohta Lindström et al. 2009).

Käesolevas artiklis otsime eesti murrete korpuse materjalidele tuginedes vastust küsimusele, kas nimetamiskonstruktsiooni varieerumisel on regionaalne mõõde, s.t kas on olulisi erinevusi murrete vahel. Milline osa varieerumisest on selgitatav murretevaheliste erinevustega, milline mitte? Neile küsimustele vastamiseks kasutame korpusest saadud sagedusandmeid ning kvantitatiivseid meetodeid nende andmete töötlemiseks: klassifitseerimispuu meetodit ning korrespondentsanalüüsi.

Artikli järgmises osas (2. ptk) tutvustame nimetamiskonstruktsioone lähemalt, seejärel arutleme põgusalt sageduse rolli üle tegeliku keelekasutuse uurimisel (3. ptk), tutvustame artiklis kasutatud andmestikku ja meetodeid (4. ptk) ning esitame uurimuse tulemused (5. ptk).

\section{Nimetamiskonstruktsioonist}

Artiklis räägime nimetamiskonstruktsioonist ja konstruktsioonisisesest varieerumisest. Konstruktsioonigrammatikas käsitletakse konstruktsioone kui kinnistunud vormi ja tähenduse kombinatsioone, millel on oma struktuurilised, semantilised või pragmaatilised erijooned (Goldberg 1995: 4; Croft 2001: 18-25; 
Hilpert 2013: 458). Konstruktsioonid paiknevad leksikoni-süntaksi skaalal, leksikoni ja süntaksi vahel puudub selge piir.

Nimetamiskonstruktsiooni moodustab umbisikulises tegumoes verb, selle objektargument ning laiend (komplement), mis väljendab, kuidas objekti nimetatakse (11).

$$
\begin{array}{lll}
\text { no sedä kutsutti } & \\
& \text { OBJ }
\end{array}
$$

Obosekivest KOMPL

Konstruktsiooni tuumaks on verb umbisikulises tegumoes: impersonaalne verbivorm väljendab eesti keeles enamasti indefiniitset, ent elusat inimesele viitavat tegijat, mis tavaliselt on kollektiivne või mitmuslik (vt nt Torn-Leesik 2009; Torn-Leesik \& Vihman 2010; Pajusalu 2015). Just impersonaalses vormis nimetamisverb, mille (implitsiitne) referent on indefiniitne, sobib eriti hästi üldiste või tavaliste olukordade kirjeldamiseks: näidet 11 võib interpreteerida nii, et väga paljud inimesed (pole tähtis, kes konkreetselt) nimetasid mingit teatud kivi (seda) Obosekiviks. Põhimõtteliselt on tegijat (s.t nimetajat) võimalik ka eksplitsiitselt määratleda (nt vanarahvas kutsus seda Obesekiviks; isa kutsus mind titaks), ent murdekorpuse tekstides on impersonaalne kasutus iseäranis sage ning seetõttu on põhjust seda kasutusviisi pidada konstruktsiooni kinnistunuks, konstruktsionaliseerunuks.

Nimetamiskonstruktsioon on murdekeeles sage ning on iseloomulik just murdeintervjuudele, kus küsitletakse keelejuhte peamiselt vanaaegse elu-olu kohta ning sageli palutakse otsesõnu murdekeelt kasutada (vt murdekorpuse tekstide iseloomustust ptk 4.1. ja Lindström 2001). Selle tulemusena kommenteerivad murdekorpuse keelejuhid tekstides sageli oma keelekasutust ning viitavad sellele, kuidas üht või teist eset/nähtust varem nimetati. Võib arvata, et tavalistes argivestlustes pole põhjust nimetamiskonstruktsiooni nii sageli kasutada.

\subsection{Verbid nimetamiskonstruktsioonis}

Verbid, mida nimetamiskonstruktsioonis kasutatakse, on kutsuma, hüüdma, nimetama, hõikama ja ütlema. Võimalik, et neid on enamgi, ent murdekorpuse materjalidest tulid esile just need. Mitte ükski nendest verbidest ei ole aga eesti ühiskeeles ega murretes ühetähenduslik, kandes vaid teatava nimega kutsumise tähendust. Ka verb nimetama, mille kaudu me vaatlusaluseid konstruktsioone nimetame ning mille puhul on mingi nimega / kuidagi kutsumise tähendus (12) peamiseks, võib lisaks kanda tähendusi 'teatama' (13) ja 'ära sõnuma' (14) (EMS VI: 581-582). 

küll teda 'rahva`riideks nimedati (Lääne, Kul; EMS VI: 581) ma nimetan tämäle midagi ‘uudist (Alutaguse, Jõh; EMS VI: 582) 'Kiita ei 'tohtind, siis nimetad ää (Saarte, Jäm; EMS VI: 582)

Kuigi räägime nimetamiskonstruktsioonist, esineb verbi nimetama meie materjalis küllaltki harva (vt sagedusandmeid tabelis 1). Sagedasimaks on nimetamiskonstruktsioonides hoopis verb kutsuma, millel on "Eesti murrete sõnaraamatu" (EMS IV: 134-135) järgi meile huvipakkuvale lisaks veel kolm tähendust: 'kedagi paluma, kellelegi ettepanekut tegema kuhugi tulla või millestki osa võtta' (15), 'loomi või linde heli, häälitsusega ligi meelitama' (16) ja 'soovima' (17).

(15) kas sind on kutsutud matussele (Ida, Lai; EMS IV: 134)

(16) uśso, uśso kutsutas voonakõist (Võru, Kan; EMS IV: 135)

(17) sääl tetäss `sü̈̈kija tuuas uma ports, mia `kuaki henele kuts (Võru, Har; EMS IV: 135)

Verbist kutsuma mõnevõrra harvem, kuid teistest verbidest siiski tunduvalt sagedasem on nimetamiskonstruktsioonis hüüdma, mis kannab "Eesti kirjakeele seletava sõnaraamatu" (EKSS) järgi lisaks veel tähendusi 'kellelegi midagi hõikama' ja 'kedagi hõigates (enda juurde) kutsuma'. Vaatlusalustest verbidest kõige harvemaks on nimetamiskonstruktsioonides hõikama (18) ja ütlema (19).

(18) sii õigatti Kiivitta külä (Mulgi, Trv)

(19) naid ütteldi oonakkõsõ (Võru, Krl)

Et verbi ütlema (19) puhul on nimetamistähendus selgelt teisejärguline ja seda tähendust kannab meie materjalis vaid 11 verbiga ütlema lauset (vt tabel 1), jäävad selle verbiga laused (kvantitatiivsest) analüüsist kõrvale.

Tabel 1. Verbilekseemide sagedused murdekorpuse nimetamiskonstruktsioonides.

\begin{tabular}{|c|c|}
\hline Verb & $\begin{array}{l}\text { Sagedus murdekorpuse } \\
\text { nimetamiskonstruktsioonis }\end{array}$ \\
\hline hõikama & 23 \\
\hline hüüdma & 346 \\
\hline kutsuma & 504 \\
\hline nimetama & 32 \\
\hline ütlema & 11 \\
\hline
\end{tabular}

Kui verbid kutsuma ja hü̈̈dma on "Väikese murdesõnastiku" (VMS) andmetel levinud üle Eesti (viimast esineb siiski vähem lõunaeesti murretes), siis verbide nimetama ja hõikama kasutusala on piiratum. Verb nimetama on sõnaraa- 
matu andmetel meile huvipakkuvas tähenduses levinud vaid Võru, Tartu ja rannamurdes, hõikama kõigis tähendustes aga idapoolses Eestis, esinedes ka üksikutes saarte murde kihelkondades ning lääne- ja keskmurde alal ainult lõuna- ja idapoolsetes kihelkondades (VMS). Tuleb meeles pidada, et verbid on mitmetähenduslikud ja VMS ei täpsusta, millist tähendust kus kasutatakse (v.a verbi nimetama puhul). Veelgi olulisem on siinkohal see, et VMSi sõnavara leviku kaardid ei anna meile otsest infot selle kohta, kui sagedasti verbe mingil alal kasutatakse. Artiklis kontrollime murdekorpuse materjali põhjal niisiis ka verbi valikut konstruktsioonis: kui tavaline on ühe või teise verbi kasutamine nimetamiskonstruktsioonis ning kui palju on selles murretevahelist leksikaalset varieeruvust.

\subsection{Objekti markeerimine nimetamiskonstruktsioonis}

Tänapäeva kirjakeeles on nimetamiskonstruktsioonis võimalik ainult osaobjekti (ehk osastavas käändes objekti) kasutamine; täisobjekt (mis impersonaalse verbivormi puhul oleks nimetavas käändes, vt EKG II: 53; Metslang 2017: 271) ei ole selles konstruktsioonis kirjakeeles võimalik (vrd 20 a ja b).

a. Seda kutsutakse Hobusekiviks.

b. *See kutsutakse Hobusekiviks.

Juba eespool esitatud näidetest 7 ja 10 näeme siiski, et murretes võib nimetamiskonstruktsioonis esineda ka nimetavas käändes objekt. Selle põhjuseid võib olla mitmeid, ent käesolevas artiklis oletame, et tegemist on konstruktsioonisisese muutusega: nimetav kääne võtab üle osastava käände kasutusala seal, kus täis- ja osaobjekti vaheldusel ei ole funktsionaalset tähenduserinevust. Sama on juhtunud näiteks ka nimetava/osastava vaheldusega mõningates mäletamiskonstruktsioonides, kus samamoodi varieerub täis- ja osasubjekti kasutus (nt mul oli see / seda meeles, vt Lindström 2017), ja tarvis / vaja-konstruktsioonides, kus võib siiski pigem eeldada muutust osastava käände üldistumisele (Lindström et al. 2014). Nimetava käände üldistumisel võib oletada murdelist levikut, sest murdekorpuse materjalide põhjal paistab, et nimetav kääne on üldistumas eelkõige läänepoolsetes murretes.

\subsection{Komplemendi markeerimine nimetamiskonstruktsioonis}

Komplemendi ehk verbi laiendi vormistus osutab, kui tugevalt on see verbi argumentstruktuuri integreeritud: saavas käändes komplement (20a) on selgelt vormistatud seotud argumendina, ent näidetes 7 ja 8 , kus see on nimetavas, 
pigem sarnaselt tsiteerimisega, kus kellegi teise sõnu antakse edasi ilma neid lausesse integreerimata.

$$
\begin{aligned}
& \text { ning igast puust `tehti neid `väiksid `pappu (...) nee [OBJ, n] } \\
& \text { kutsutti = sis kippud [KOMPL, n] `ikke (Saarte, Ans) } \\
& \text { ja siis seda }[\mathrm{OBJ}, \mathrm{p}] \text { ‘kutsutti obaduse auk [KOMPL, n] }
\end{aligned}
$$
(Alutaguse, Iis) ja pulk ol' iihh ja säält 'las'ti liim ‘vällä (.) õ = kutsut't’i et koore kä̈r'n' [KOMPL, n] (Võru, Rõu)

Komplement on veelgi nõrgemalt argumentstruktuuri integreeritud, kui lisandub sidend et (9), mis on eesti keele kõige sagedasem ja ühtlasi ka kõige enam funktsioone kandev alistav sidesõna, mistõttu on seda peetud eesti keele üldalistavaks sidendiks (vt Plado 2013: 22, 36). Teiselt poolt osutab sidendi kasutamine, et kõneleja tunneb vajadust tsiteeritavat üksust verbi külge kuidagi siduda ning vormistab selle siis komplementlause taoliselt: ühelt poolt markeeritakse see alistava sidendiga et, kuid teiselt poolt erineb see komplementlausetest selle poolest, et see koosneb vaid (enamasti ühesõnalisest) tsitaadist ega sisalda verbi. Samuti ei saa eesti kirjakeele süntaksikäsitluse järgi (Erelt 2017: 672-677) nimetamisverbidega esineda et-komplementlause. Suulises kõnes kasutatakse nii kõne kui ka mõtete refereerimist palju ning seda tehakse nii otse- kui ka kaudkõnet kasutades, eriti iseloomulik on aga nende vahepealse variandi, n-ö siirdkõne kasutamine; seejuures sageli pole referaatosa selgelt markeeritud (Hennoste 2004: 507). Nimetamiskonstruktsioone eristab tüüpilistest komplementlausetest / otsesest kõnest referaatosa lühidus (enamasti üks sõna või fraas), mis teeb nende käsitlemise eriti keerukaks: raske on öelda, kas nimetavas käändes komplement (7-9) on otsene tsiteerimine või väljakujunenud komplemendi markeerimise viis (nagu saavas käändes komplemendi puhul võib öelda).

Käesolevas artiklis lähtume oletusest, et lõtv argumentide sidumine on pigem suulise kõne omapära. Kuna suuline kõne on lineaarne ning temporaalselt piiritletud (s.t toimub reaalajas ja seda piiritleb kõnetempo), on kõnelejal vähem võimalusi oma lausungit süntaktiliselt põhjalikult läbi töötada ning seetõttu ei ole suulise kõne laused/lausungid üldjuhul nii komplekssed kui kirjakeeles. (Vt nt Auer 2009 kõne temporaalsusest tulenevate süntaktiliste erijoonte kohta.) Teiselt poolt on lõtv argumentide sidumine seotud ka kõnes toimuva sagedase tsiteerimisega/refereerimisega (vt ka Hennoste 2004, 2001): tsitaat jääb tüüpiliselt argumendiks sidumata, ent kui tsitaat on lühike ja koosneb ühest nimisõnafraasist (nagu nimetamiskonstruktsioonis), võib ta teatud vormis ka kinnistuda argumentstruktuuri. 
Artiklis vaatleme nimetamiskonstruktsioonide varieerumist eesmärgiga välja selgitada, kas tegemist on pigem suulisusest tingitud nähtusega või on murrete vahel olulisi erinevusi argumentide sidumisel lausestruktuuri. Kui tegemist on pelgalt teksti suulisusest tingitud nähtusega, võiksime eeldada, et erinevate kasutusmallide jaotumisel murrete vahel olulisi erinevusi ei ole. Kui aga erinevused ilmnevad, s.t kui teatud kasutusmustrid on iseloomulikud teatud piirkondadele, võime rääkida murdeerinevustest.

\section{Sagedusest}

Käesolev uurimus toetub eesti murrete korpusele ning kasutab korpusest saadud sagedusandmeid. Sageduse rolli ja mõju keelenähtuste kujunemisele ja muutumisele on viimastel kümnenditel uuritud üsna palju (vt nt Arppe et al. 2010; Divjak \& Gries 2012; Gries \& Divjak 2012), eriti kasutuspõhises lähenemises keelele (vt nt Barlow \& Kemmer 2000; Bybee 2010) ning see on eriti tavaline varieerumise uurimisel. Ka murdesüntaksi-alastes töödes on rõhutatud sagedusandmete vajalikkust, sest süntaktilise varieerumise puhul ei saa sageli teha selgeid kategoriaalseid eristusi (nähtus x esineb, y mitte), vaid pigem eristada tüüpilist ebatüüpilisest sageduse põhjal (Kortmann 2010). On leitud, et tekstisagedused peegeldavad keeletaju paremini kui traditsiooniliselt dialektoloogias kasutatavad atlasandmestikud (Szmrecsanyi 2013: 4).

Sageduserinevused võivad olla olulised ka keelekontaktidele osutajana: teatud kasutusmustrid võivad kontakti situatsioonis muutuda oluliselt sagedasemaks, kui kontaktkeeles on analoogiline kasutusmuster olemas (Heine \& Kuteva 2005: 47). Isegi kui teatav nähtus on levinud mitmes piirkonnas, on kasutussagedus oluliselt väiksem väljaspool vaadeldava kontaktala tuuma (vt Koptjevskaja-Tamm \& Wälchli 2001: 627). Seega võib kasutussagedus osutada ka võimalikule kontaktist tingitud muutusele.

Varasemad korpuspõhised uurimused eesti murrete kohta osutavad, et sagedusandmed eristavad murdeid üsna hästi. Sageli võib seda siduda ka keelekontakti mõjuga, kui kontaktkeeles on sarnane nähtus olemas või vastupidi, puudub (vt nt täis- ja ennemineviku kohta Lindström et al. 2015, avaldamisel, tarvis / vaja-konstruktsioonide kohta Lindström et al. 2014; Lindström \& Uiboaed 2017). Teisalt võib teatud juhtudel kasutussagedus osutada ka, et mingi piirkond on teatud laiaulatuslikuma muutuse osas teistest konservatiivsem. Nii näiteks eelistavad samatähenduslike adessiiviga (nt laual) ja kaassõnaga peal (laua peal) konstruktsioonide valiku puhul Alutaguse ja rannamurre sünteetilist varianti (laual) (Klavan et al. 2015), mida võib läänemeresoome keeltes pidada konservatiivsemaks ja vanemaks jooneks kui kaassõnakonstruktsiooni. 
Piirkondlikud sageduserinevused võivad seega osutada tugeva keelekontakti olemasolule, aga ka selle puudumisele. Lisaks on võimalik, et teatud piirkonnas on toimunud konstruktsioonisisesed eriarengud, mida pole otseselt võimalik pidada keelekontaktist tingituks.

Käesolevas artiklis me otseselt keelekontaktidest selgitusi ei otsi. Artikli peamine küsimus on, kas nimetamiskonstruktsioonide varieerumises on võimalik eristada piirkondlikke eripärasid, s.t kas on olulisi erinevusi eesti murrete vahel.

\section{Andmed ja meetodid}

\subsection{Murdekorpusest}

Analüüsi aluseks olev andmestik on pärit eesti murrete korpusest (vt kirjeldust www.keel.ut.ee/et/keelekogud/murdekorpus). Murdekorpuse tekstid sisaldavad suulisi murdeintervjuusid, mis on läbi viidud põhiosas 1960.-1970. aastatel (vt Lindström 2015). Helisalvestised on litereeritud ja morfoloogiliselt märgendatud ning neid võib näha ka veebipõhises otsimootoris www.murre.ut.ee/mkweb/. Murdekorpuse tekstid on pärit kahest arhiivist: Eesti Keele Instituudi eesti murrete ja soome-ugri keelte arhiivist (emsuka.eki.ee; vt kirjeldust Ermus \& Kalvik \& Laansalu, ilmumas) ja Tartu Ülikooli eesti murrete ja sugulaskeelte arhiivist (www.murre.ut.ee/arhiiv/; vt kirjeldust ka Lindström \& Lippus \& Tuisk, ilmumas).

Tekstiliselt on murdekorpuses põhiosas traditsioonilised murdeintervjuud, mis käsitlevad suuremalt jaolt endisaegset elu-olu. Intervjuud võivad sisaldada pikemaid narratiivseid lõike: eluloolist narratiivi, legende, vähesel määral ka muinasjutte. Küllalt suur osa tekstidest käsitleb endisaegsete tööde kirjeldusi.

Murdekorpuse informandid on valdavalt vanemad inimesed, kes on olnud paiksed, sündinud ja kasvanud samas piirkonnas, suhteliselt vähe haritud ning intervjueerijate hinnangul esindavad vanapärast kohapealset murdekeelt. Murdekorpuse informantide sünniaeg jääb enamasti 1870.-1880. aastatesse.

Murdekorpus sisaldab tekste kõigist eesti murretest, ent mitte kõigist kihelkondadest ja murrakutest. ${ }^{3}$ Analüüsis järgime murdekorpuse murdejaotust.

\subsection{Murdejaotusest}

Eesti murded on traditsiooniliselt jagatud põhjaeesti ja lõunaeesti murderühmaks. Nende kahe pearühma erinevused on sedavõrd suured, et neid on peetud omaette hõimukeeltest kujunenuteks. Põhja- ja lõunaeesti murderühma vahel 
on suured erinevused nii häälikulises, morfoloogilises kui ka sõnavaralises plaanis. Põhjaeesti murderühmast on eristatud hiljem kirderanniku murderühm, millel on vanad süstemaatilised erinevused muudest põhjaeesti murretest (Kask 1984). Kirderanniku murderühma sees eristatakse rannamurret ja Alutaguse ehk kirdemurret.

Käesolevas töös kasutame murdeõpikus (Pajusalu et al. 2009) esitatud murdejaotust, mis on olnud aluseks eesti murrete korpuse murdejaotusele. Peamise erinevusena murdeõpikust on Võru murdest eristatud Seto murre; murdeõpikus käsitletakse Seto murderühma Võru murde koosseisus (Pajusalu et al. 2009). Vähemalt süntaktiliste joonte käsitluses on see eristus olnud õigustatud, kuivõrd Seto on osutunud muust Võru murdest oluliselt erinevaks mitmete süntaktiliste joonte poolest (vt nt Uiboaed 2013; Lindström et al. 2014; Lindström 2017). Töös kasutatud murdejaotust illustreerib kaart 1, millel on esitatud kümme eesti peamist kohamurret: kirderanniku murderühma kuuluvad Alutaguse ja rannamurre; põhjaeesti murderühma kuuluvad idamurre, keskmurre, läänemurre ja saarte murre; lõunaeesti murderühma kuuluvad Mulgi, Seto, Tartu ja Võru murre.

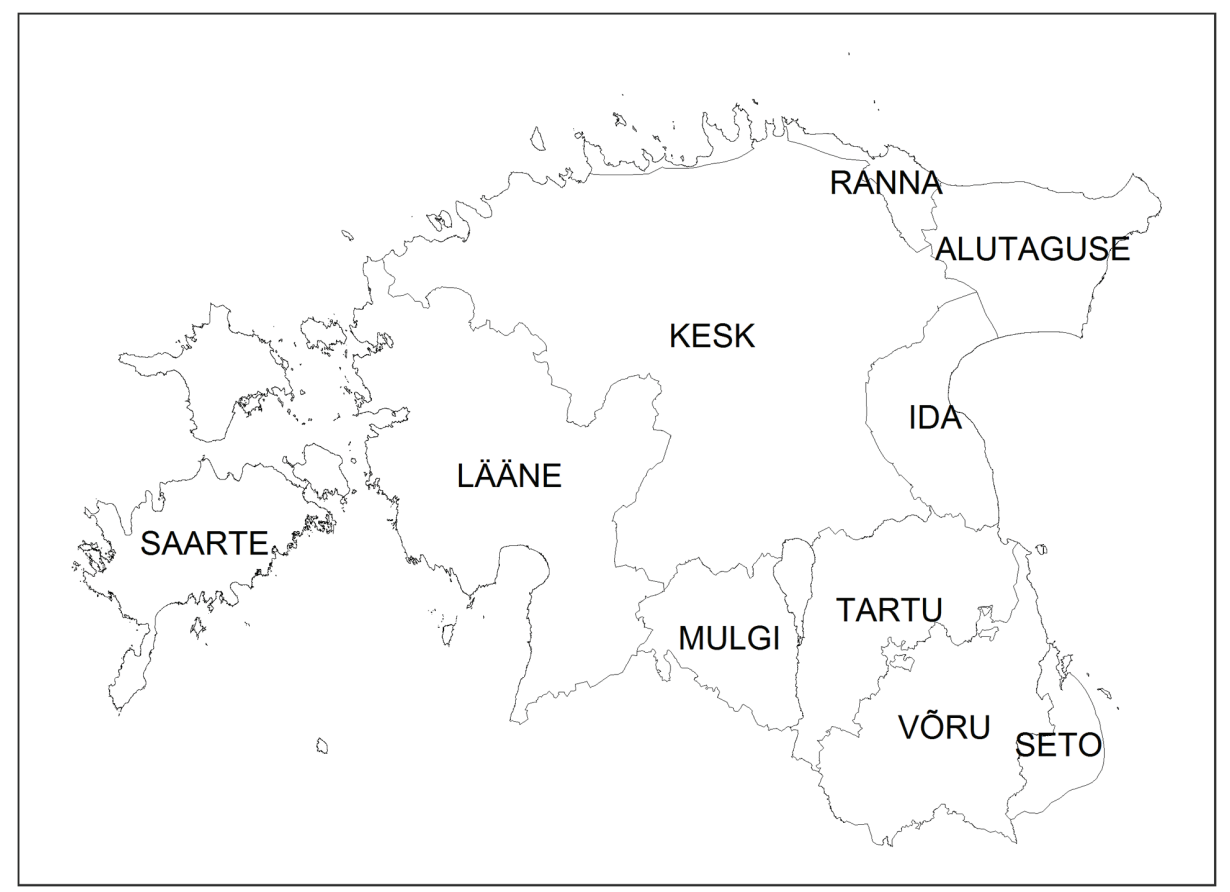

Kaart 1. Eesti murdekaart. 


\subsection{Andmestik}

Andmestik on pärit eesti murrete korpuse morfoloogiliselt märgendatud osast, mis andmete kogumise hetkel sisaldas 834311 märgendatud sõna. Korpus sisaldab materjali kõigist kümnest ülalnimetatud eesti kohamurdest, ehkki erineval määral. Seepärast oleme murrete omavaheliseks võrdlemiseks nähtuste absoluutsagedusi normaliseerinud 100000 sõna kohta.

Korpusest otsisime välja kõik hõikama, hüüdma, kutsuma, nimetama ja ütlema impersonaali vormide esinemisjuhud ning tuvastasime, millised nendest esinevad nimetamiskonstruktsioonis. Kuna ütlema osutus nimetamiskonstruktsioonides harvaesinevaks ning ühtlasi keerukalt analüüsitavaks verbiks, jätsime selle verbiga moodustatud nimetamiskonstruktsioonid analüüsist välja. Ühtekokku jäi andmestikku 905 nimetamiskonstruktsiooni.

Andmestikus kodeerisime viis tunnust. Tunnused ja nende tasemed on esitatud tabelis 2 .

Tabel 2. Andmestikus kodeeritud tunnused ja nende tasemed.

\begin{tabular}{|c|c|c|c|}
\hline Tunnus & Tasemed & Selgitus & Näide \\
\hline VERB & $\begin{array}{l}\text { hõikama } \\
\text { hüüdma } \\
\text { kutsuma } \\
\text { nimetama }\end{array}$ & & \\
\hline KOMPLEMENT & $\begin{array}{l}\text { vorm_t } \\
\text { vorm_n } \\
\text { vorm_pro } \\
\text { vorm_muu } \\
\text { vorm_ei }\end{array}$ & $\begin{array}{l}\text { translatiiv e } \\
\text { saav kääne } \\
\text { nominatiiv e } \\
\text { nimetav kääne } \\
\text { proadverb e } \\
\text { asemäärsõna; küsiv- } \\
\text { siduv määrsõna } \\
\text { (kõrval)lause; } \\
\text { infiniitne verbi- } \\
\text { konstruktsioon; } \\
\text { adpositsiooni- ehk } \\
\text { kaassõnafraas } \\
\text { komplement } \\
\text { välja jäetud }\end{array}$ & $\begin{array}{l}\text { Teda kutsuti } \\
\text { kuningaks. } \\
\text { Teda kutsuti } \\
\text { kuningas. } \\
\text { Teda kutsuti } \\
\text { niimoodi; } \\
\text { Kuidas teda kutsuti } \\
\text { Neid kutsuti, et setod } \\
\text { on koorma peal; } \\
\text { Kutsuti linu ürsima; } \\
\text { Väärnime pidi } \\
\text { kutsuti } \\
\end{array}$ \\
\hline OBJEKT & $\begin{array}{l}o b j \_p \\
o b j \_n \\
o b j \_l \\
o b j \_e i\end{array}$ & $\begin{array}{l}\text { partitiiv e } \\
\text { osastav kääne } \\
\text { nominatiiv e } \\
\text { nimetav kääne } \\
\text { (kõrval)lause } \\
\text { objekt välja jäetud }\end{array}$ & $\begin{array}{l}\text { Teda kutsuti kunin- } \\
\text { gaks. } \\
\text { See kutsuti karuägel. } \\
\text { Käsipuu kutsuti, } \\
\text { kust kätega kinni } \\
\text { hoidsid. } \\
\text { - }\end{array}$ \\
\hline
\end{tabular}




\begin{tabular}{|l|l|l|l|}
\hline SIDEND & $\begin{array}{l}\text { sidend_jah } \\
\text { sidend_ei }\end{array}$ & $\begin{array}{l}\text { sidend olemas } \\
\text { sidend puudu }\end{array}$ & $\begin{array}{l}\text { Seda kutsuti, et sõõrd. } \\
\text { Seda kutsuti sõõrd. }\end{array}$ \\
\hline MURRE & Alutaguse & & \\
& Ida & & \\
Kesk & & \\
Lääne & & \\
Mulgi & & \\
Ranna & & \\
& Saarte & & \\
& Seto & & \\
& Tartu & & \\
& Võru & & \\
&
\end{tabular}

\subsection{Meetodid}

Selleks, et selgitada, millistest teguritest sõltuvad objekti ja komplemendi vorm ning konstruktsioonis esinev verb, kasutame klassifitseerimispuude meetodit (Breiman et al. 1984; Hothorn et al. 2006). Meetod põhineb andmestikus olevate vaatluste korduval ositamisel ehk klassidesse jagamisel ning võimaldab visualiseerida ka keerulisemaid interaktsioone (klassifitseerimispuude kasutamisest eesti keele uurimisel vt nt Klavan et al. 2015; Ruutma et al. 2016; Lindström \& Vihman 2017; Taremaa 2017). Vaatlus on põhimõtteliselt üks rida andmestikus, mis sisaldab nii uuritava tunnuse mingit väärtust kui ka kõiki selle väärtusega koos esinevaid seletavate tunnuste väärtusi. Kõik vaatlused jagatakse binaarsetesse klassidesse vastavalt sellele, kui tugevalt mingi kodeeritud seletav tunnus (nt murre) uuritava tunnusega (nt konstruktsioonis esinev verb) seotud on. Kõige olulisem seletav tunnus annab enamasti puu esimese hargnemise ja kumbagi harusse grupeeritakse selle tunnuse alusel sarnased vaatlused. Seejärel jätkub ositamine kahes harus vastavalt järgmistele olulistele seletavatele tunnustele nendes harudes, seejärel nende tunnuste põhjal hargnenud klassides jne. Jagunemine kestab seni, kuni edasine jagamine pole enam põhjendatud, s.t statistiliselt pole järgnevad tunnused enam vaatluste klassifitseerimise seisukohalt olulised. Protsessi lõpptulemusena peaksid kõik vaatlused olema jagatud uuritava tunnuse suhtes optimaalselt rühmadesse. (Strobl et al. 2009: 325-327.)

Tunnuste tasemete sageduspõhise jaotumise ning tunnuste omavaheliste suhete visualiseerimiseks kasutame lisaks lihtsat korrespondentsanalüüsi (vt Greenacre 2006, 2007). Korrespondentsanalüüsis võrreldakse kahemõõtmelise sagedustabeli (risttabeli) ridades ja veergudes olevate väärtuste vahelisi sageduspõhiseid suhteid, ning analüüsi üks väljund on kahemõõtmeline graafik, mis võimaldab neid suhteid kauguste abil visuaalselt esitada. Analüüs võimaldab 
niisiis selles uurimuses visualiseerida, millised tunnused teiste tunnustega koos esinevad, ning avastada seeläbi keelekasutuses esinevaid mustreid. Graafikule valitud kaks mõõdet seletavad suurima osa ridade ja veergude vahelisest seosest ning graafikul kujutatud üksustevahelisi kaugusi võib nende kahe mõõtme põhjal tõlgendada sama tüüpi tunnuste puhul nende tunnuste omavaheliste sarnasuste ja erinevustena, eri tüüpi tunnuste puhul aga nende tunnuste tõmbumise ja tõukumisena. Korrespondentsanalüüsi näol on tegu andmete esmase, uuriva analüüsiga, mis tähendab, et selle abil saab eelkõige leida koosesinemise mustreid, ent meetod üksi ei võimalda teha järeldusi tunnuste olulisuse kohta või tõestada tunnuste vahel põhjuslikke suhteid (Glynn 2014: 134). Korrespondentsanalüüs sobib paremini sagedaste ja ilmsete korrelatsioonide kuvamiseks ning töötab veidi halvemini harvemate tunnusekombinatsioonide eristamisel. Väga sagedased ja üldised nähtused kipuvad graafikul paiknema graafiku telgede ristumispunktis, viidates sellele, et nende roll korrelatsioonide tuvastamisel on võrdlemisi väike, samas kui väga harvad nähtused võivad paikneda graafiku äärealadel ning mingi teise tunnusega väga tugevalt seostudes mõjutada ka ülejäänud tunnuste vahelisi kaugusi. Seepärast peab graafiku tõlgendamisel silmas pidama, et ehkki analüüsis kasutud hii-ruut-kaugused pürgivad esitama võimalikult täpset üldistust ridade ja veergude korrelatsioonist, illustreerib graafik tulemusi siiski ainult ligikaudselt (Baayen 2008: 139-146).

\section{Tulemused}

Vaatlesime andmestikus nii konstruktsiooni osade omavahelisi suhteid, s.t seda, millises vormis konstruktsioon ja selle elemendid sagedamini murdekorpuses esinevad, kui ka konstruktsioonide varieerumist eri murrete lõikes.

Nagu öeldud, analüüsisime murdekorpusest 905 nimetamiskonstruktsiooni. Nende jaotumist murrete lõikes illustreerib tabel 3.

Ehkki normaliseeritud sageduste põhjal võib väita, et nimetamiskonstruktsioonid on märkimisväärselt sagedamad saarte, Võru ja Seto murdes (esitatud paksus kirjas), ei ole need sageduserinevused tõenäoliselt keeleliselt motiveeritud, vaid seotud pigem tekstide temaatikaga. On muidugi võimalik, et konstruktsiooni kasutamist on suurendanud ka nende murrete erinevus standardkeelest: keelejuht peab rohkem selgitama ühe või teise sõna või nähtuse tähendust. See selgitus jääb siinkohal siiski spekulatiivseks ning kasutusjuhtude vaatlemine meile rohkem tuge ei pakkunud.

Järgnevalt vaatleme lähemalt nimetamiskonstruktsiooni osade (objekti, komplemendi ja verbi) varieerumist andmestikus. Esitame iga uuritava tunnuse kohta esmalt klassifitseerimispuu, mis illustreerib uuritava tunnuse väärtuste 
sõltuvust teistest mudelisse kaasatud tunnustest. Seejärel täiendame analüüsi olulisemate klassifitseerimispuus esile tulnud tunnusekombinatsioonide uurimisega korrespondentsanalüüsi graafikute ning risttabelite abil. Objektargumendi ja komplemendi vormi uurime peaasjalikult nende konstruktsioonide põhjal, milles vastavad elemendid on väljendatud, kuna eeldame, et nende väljajätt on tingitud pigem suulise diskursuse eripäradest kui lingvistilistest faktoritest. Eelduse kontrollimiseks ja tulemuste adekvaatsemaks tõlgendamiseks võrdleme väljundit siiski ka väljajättu sisaldavate mudelitega, kuna väljajäetud elementide kaasamine annab lisainfot teiste konstruktsiooni osade sagedamate kombinatsioonide kohta.

Tabel 3. Konstruktsioonide esinemissagedus korpuses murdeti.

\begin{tabular}{|l|l|l|l|}
\hline Murre & $\begin{array}{l}\text { Konstruktsiooni } \\
\text { absoluutsagedus }\end{array}$ & Sõnu korpuses & $\begin{array}{l}\text { Konstruktsiooni } \\
\text { normaliseeritud } \\
\text { sagedus } \\
(\mathbf{1 0 0} \text { o00 sonna kohta) }\end{array}$ \\
\hline Kesk & 132 & 130086 & 101 \\
\hline Mulgi & 56 & 63516 & 89 \\
\hline Alutaguse & 27 & 47660 & 56 \\
\hline Ida & 10 & 45280 & 22 \\
\hline Lääne & 90 & 154400 & 59 \\
\hline Ranna & 33 & 51667 & 64 \\
\hline Saarte & 319 & 166898 & $\mathbf{1 9 1}$ \\
\hline Seto & 60 & 39175 & $\mathbf{1 5 4}$ \\
\hline Tartu & 61 & 65591 & 93 \\
\hline Võru & 117 & 70038 & $\mathbf{1 6 7}$ \\
\hline
\end{tabular}

\subsection{Objekti varieerumine}

Nimetamiskonstruktsiooni objekti käände markeerimise jaotus murrete vahel on esitatud joonistel 1 (klassifitseerimispuu) ja 2 (korrespondentsanalüüs).

Nagu ilmneb jooniselt 1, sõltub objektargumendi (tegevuse objekti e sihitise) markeerimine (juhul, kui objektargument on väljendatud) eelkõige murdest, mis annab esimese (ja kõige olulisema) hargnemise. Rühmas, kuhu kuuluvad Alutaguse, ida-, ranna-, Seto ja Võru murre, väljendatakse objekti enamvähem võrdselt nii nimetavas ( $n$ ) kui ka osastavas ( $p$ ) käändes (vt joonisel $N_{o d e}^{4} 5$ ). Rühmas, kuhu kuuluvad kesk-, Mulgi, lääne-, saarte ja Tartu murre, seletab objekti vormi varieerumist lisaks murdealale ka komplemendi vorm: 


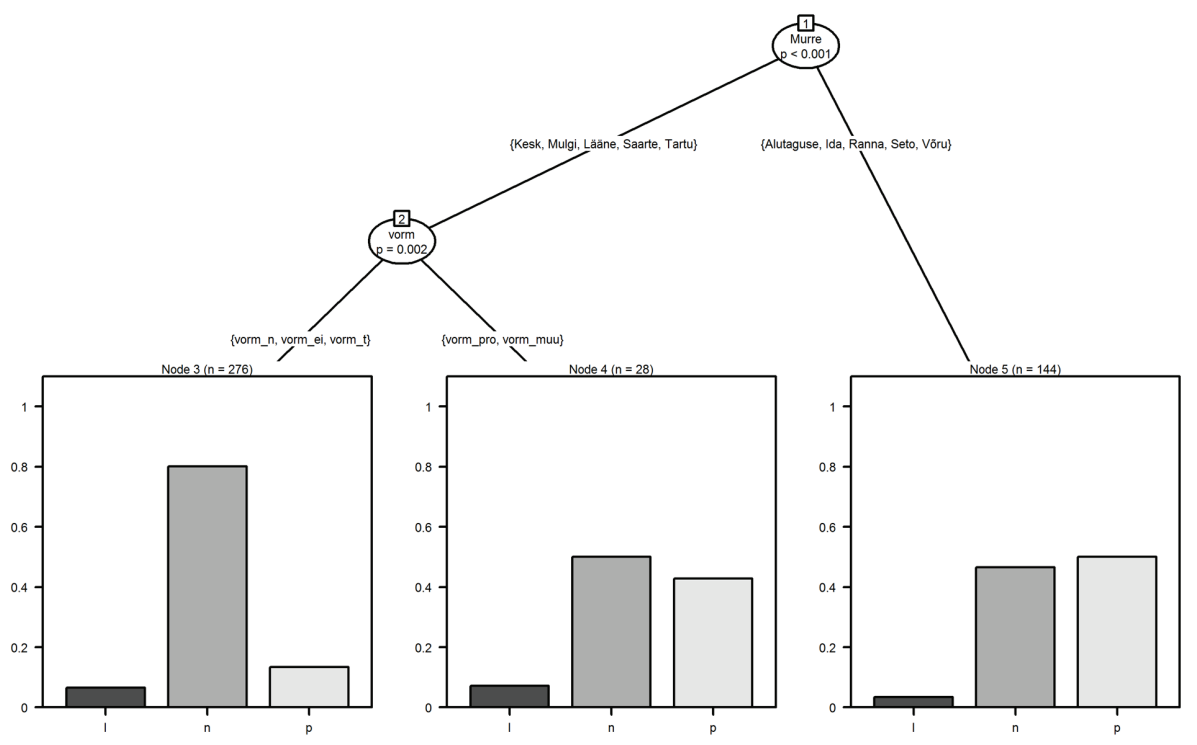

Joonis 1. Objektargumendi vormi mõjutavad tegurid klassifitseerimispuus.

kui komplement on (ase)määrsõna, lause, infiniitne verbikonstruktsioon või kaassõnafraas, on nimetava ja osastava käände proportsioonid samuti enamvähem samad (selliseid juhte on kokku küll vaid 28, Node 4); kui komplement on aga nimetavas või saavas käändes või sootuks lausest välja jäetud (Node 3), esineb selles murderühmas ülekaalukalt rohkem ( $80 \%$ juhtudest) nimetavas käändes objekti (21-23). Lauseliste objektargumentide $(l)$ osakaal on marginaalne mõlemas murderühmas, ent on siiski mõnevõrra suurem viimases. Seega võib öelda, et nimetav kääne objekti markeerimisel on iseloomulikum pigem läänepoolsematele murretele ja Tartu murdele; idapoolsemates murretes on varieerumist enam.

ja sie [OBJ, n] ‘üitti siis `kiedukuok [KOMPL, n] (Kesk, Amb) sii [OBJ, n] eigatti Linnumäess [KOMPL, t] (Mulgi, Pst) nee [OBJ, $\mathrm{n}]$ kutsutti siis jälle surtte (...) mis pagan = ne olid niid (Saarte, Ans)

Murrete erinevus on näha ka korrespondentsanalüüsi graafiku (joonis 2) põhjal. Nimetav kääne on objekti markeerimisel valdav kesk-, lääne-, Mulgi, saarte ja Tartu murdes. 
a murre a obj

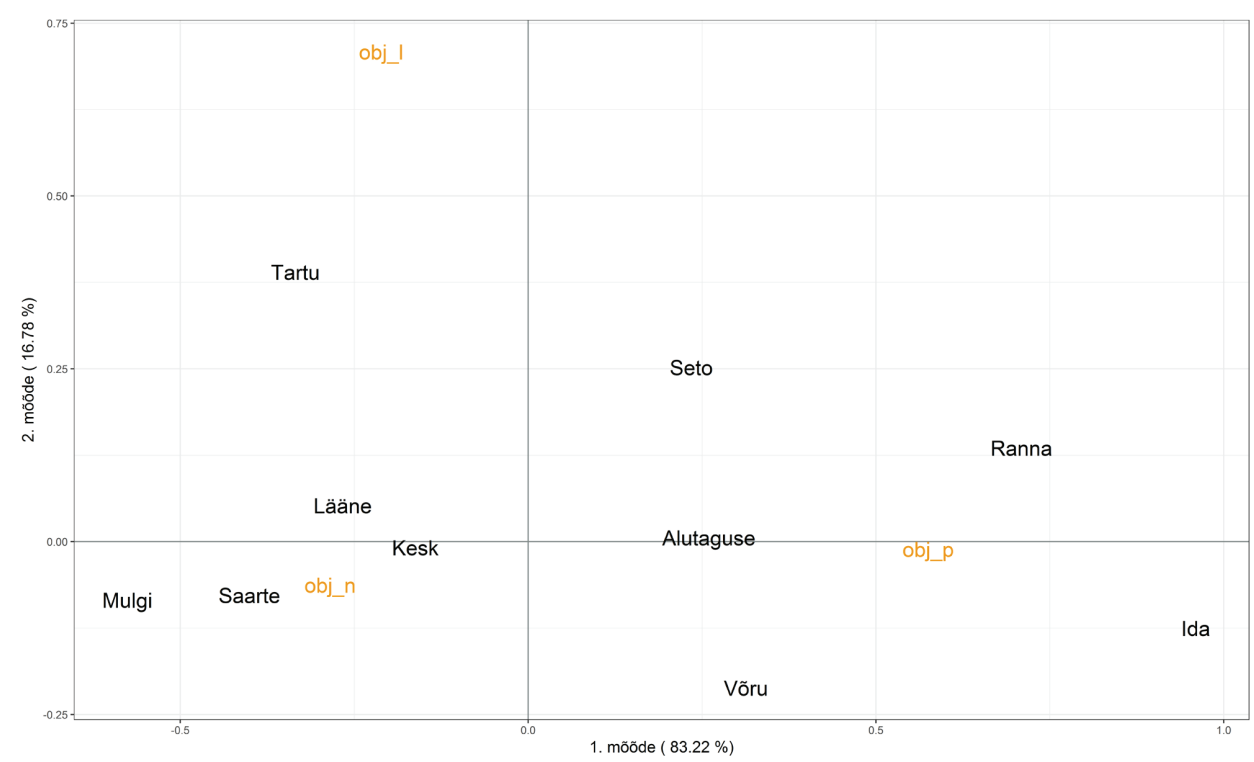

Joonis 2. Lihtne korrespondentsanalüüs objektargumendi ja murde suhetest.

Korrespondentsanalüüsi graafikult võib samuti näha, et 1. mõõde, mis seletab suure osa ridade ja veergude (ehk objekti vormi ning murrete) korrelatsioonist $(83,22 \%)$, jagab murded rühmadesse nimetavas ja osastavas käändes oleva objektargumendi põhjal. Nimetavas käändes objektile on graafiliselt kõige lähemal ning seega sellega sageduspõhiselt lähemalt seotud kesk-, lääne-, Mulgi, saarte ja Tartu murre; osastavas käändes objekti esineb aga pigem Alutaguse, ida-, ranna-, Seto ja Võru murdes. Graafiku teise mõõtme tekitab lauselise objektargumendi esinemine, ent kuna selle esinemissagedus on teistega võrreldes marginaalne, paikneb see kõigist murretest küllaltki kaugel ning teise mõõtme panus sageduspõhiste seoste seletamisse on väga väike (kõigest 16,78\%).

Selleks, et kontrollida, kas eelpool esile tulnud tunnused säilitavad oma olulisuse ka objektargumendi väljajätuga lausetes (viidates sellele, et väljajätu tingivad pigem tekstisisesed viitamis- ja infostruktuurifaktorid kui murdeerinevused), kaasasime analüüsi ka obj_ei väärtusega vaatlused. Tulemused on esitatud joonisel 3.

Jooniselt 3 näeme, et ka objekti väljajätuga lauseid sisaldavas analüüsis toimus kõige olulisem esmane jagunemine samade murrete põhjal nagu eelnevas analüüsis. Objekti väljendamine või väljajätt ei ole seega murderühmade tekkimise puhul primaarne eristav tunnus: põhilised erinevused võime lugeda tulenevat siiski nimetavas käändes objekti esinemissagedusest eri murretes. Küll aga mõjutab objekti väljajätu sagedus puu edasisi hargnemisi. 


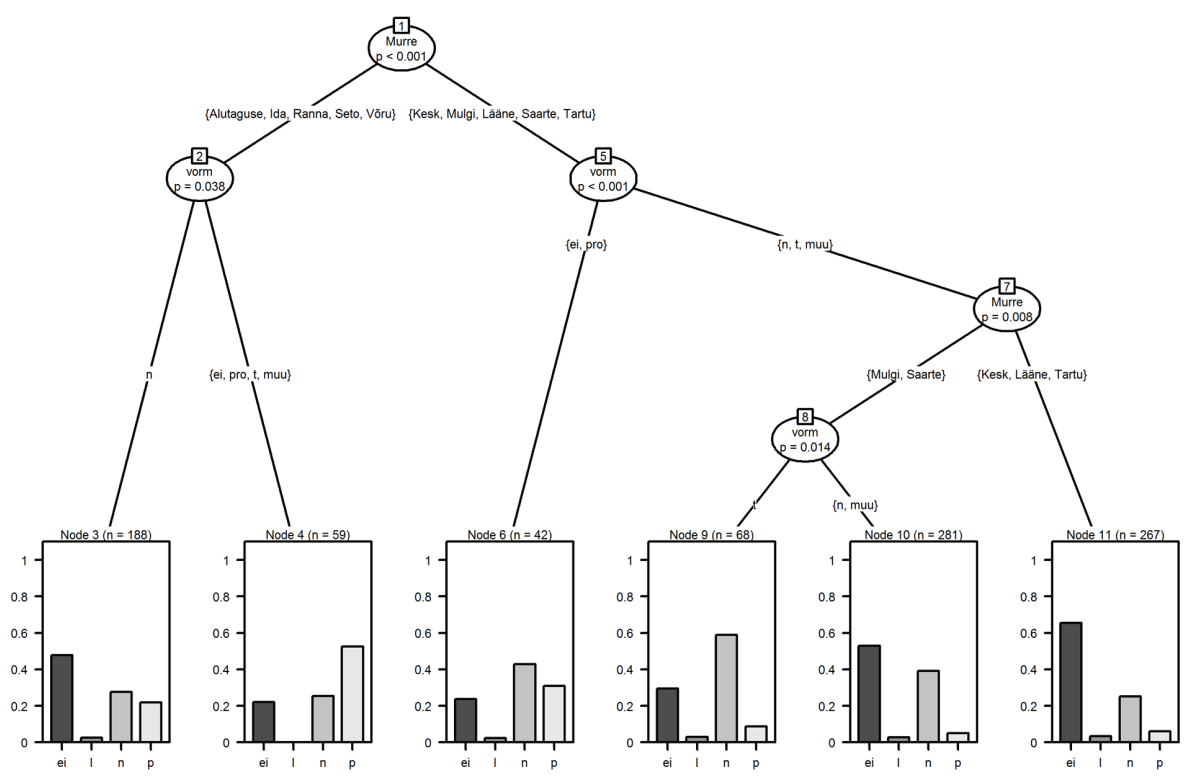

Joonis 3. Objektargumendi vormi ja väljajättu mõjutavad tegurid klassifitseerimispuus.

Alutaguse, ida-, ranna-, Seto ja Võru murde rühmas esineb objektargumendi väljajättu (24) enam juhul, kui komplement on nimetavas käändes (Node 3), ehkki kui objekt on väljendatud, esineb ta enam-vähem võrdselt nii nimetavas kui ka osastavas käändes. Teiste komplemendi vormidega esineb objektargument kõige sagedamini osastavas käändes (25-26), samas kui väljajätu (27) ja nimetava käände (28) proportsioonid on võrdsed (Node 4). Vaadates lähemalt andmestikku, ilmneb, et selle rühma 31 osastavas käändes objektist esineb vaid kolm lausetes, milles komplement on välja jäetud, millest võib järeldada, et kirjakeelele omase osastavas käändes oleva objektargumendi esinemise tõenäosus Ida-, Kirde- ja Kagu-Eesti murretes kasvab, kui komplement on kirjakeelele sarnaselt markeeritud saava käändega; nõrgemini verbi argumentstruktuuri integreeritud (s.t nimetavas käändes) komplemendi puhul aga jäetakse objekt pooltel juhtudel konstruktsioonist sootuks välja.

tul'l' = see liha 'võttõ paast (...) suur paast $[\mathrm{KOMPL}, \mathrm{n}] \underline{\text { kutsut't’i}}$ (Seto, Ida-Seto)

seda [OBJ, p] *üitti *Panttualuseks [KOMPL, t] sial (Ranna, Jõe) nu siss siin (.) tõõn'õ tarõ = mann taat $[\mathrm{OBJ}, \mathrm{p}]=\underline{\text { kutsut't'i }}$ küll väär'+nimme pitten [KOMPL, muu] (Võru, Rõu) 
Känts õli *jälle sie nimi (.) siis *ü̈̈wetti ett (.) minu mehe (.) emälõliesimine miesõliôli üks(.)*Käntsi Juhan(.)(Alutaguse,Lüg) see [OBJ, n] (.) kutsuttasse sedä+`viis'i [KOMPL, pro] = et (.) `kanga aad üles (Ida, Trm)

Murretes, kus konstruktsioonis esineb objekt sagedamini nimetavas käändes (kesk-, lääne-, Mulgi, saarte ja Tartu murde rühm), mõjutab objekti väljendamist ka komplemendi vorm: objekti väljajätt on märksa harvem ja osastava käände kasutamine sagedasem (Node 6), kui komplement puudub või on (ase)määrsõna (29), ehkki nimetavas käändes objekt on sel juhul ikkagi kõige sagedasem (30). Teistel juhtudel tekivad erinevused edasistel hargnemistel selle põhjalt, milline on väljajätu ja nimetavas käändes oleva objekti sageduste suhe. Väljajätt (31) on sagedasem (ja nimetavas käändes objekt harvem) kesk-, lääne- ja Tartu murdes (Node 11), suhe on vastupidine Mulgi ja saarte murdes, kui komplement on saavas käändes (Node 9, näide 32), ning enam-vähem võrdne muude komplemendi vormide puhul (Node 10, näide 33).

`kutnikkud olid (...) seda [OBJ, p] kutsutti see tuli üks+kord (.) see on üks `Petseri(-) (.)’Petserist tulnd söna (.)`kutnik(Saarte, Pha) 'otta miss+mood [KOMPL, pro] see [OBJ, n] kutsutti (...) ei mä̈̈letta (Kesk, HMd)

siss $\underline{\text { kutsut'ti }}$ tu $=$ omm nar'its [KOMPL, muu] (.) (Tartu, Võn) sii [OBJ, n] ô oigatti Läädsälinnass [KOMPL, t] siss (Mulgi, Trv) ole ergud punased `mette (.) sehuksed tumed punased `ollid (...) üitti madara+punased [KOMPL, n] (Saarte, Muh)

Kui kaasata objekti väljajätt ka korrespondentsanalüüsi, ilmneb ka seal (joonis 4), et lisaks nimetava ja osastava käände sagedustele eristab murdeid ka objekti väljajätt: objekt jäetakse proportsionaalselt sagedamini välja kesk-, lääne- ja Tartu murdes. Sellele, miks objektargumendi väljajätt aga just nendes murretes sagedamini esineb, on keeruline leida adekvaatset seletust.

Kokkuvõttes võib öelda, et objekti markeerimisel nimetamiskonstruktsioonis on esmased murretevahelised erinevused, seda eriti nimetava ja osastava käände kasutamise vahekorra osas. Osastav, mis on konstruktsioonis kohustuslik ka kirjakeeles, esineb sagedamini idapoolses rühmas (analüüsi põhjal kuuluvad siia idamurre, rannamurre, Võru, Seto ja Alutaguse murre) ning nimetava käände kasutamine on iseloomulikum läänepoolsematele murretele (keskmurre, saarte murre, läänemurre, Tartu ja Mulgi murre). Selline jaotus erineb oluliselt traditsioonilisest murdejaotusest, kus peamine erinevus ilmneb põhja- ja lõunaeesti murrete vahel. Objekti käände valikut mõjutavad ka muud tegurid, eelkõige komplemendi vorm: saava käändega markeeritud komplemendiga 


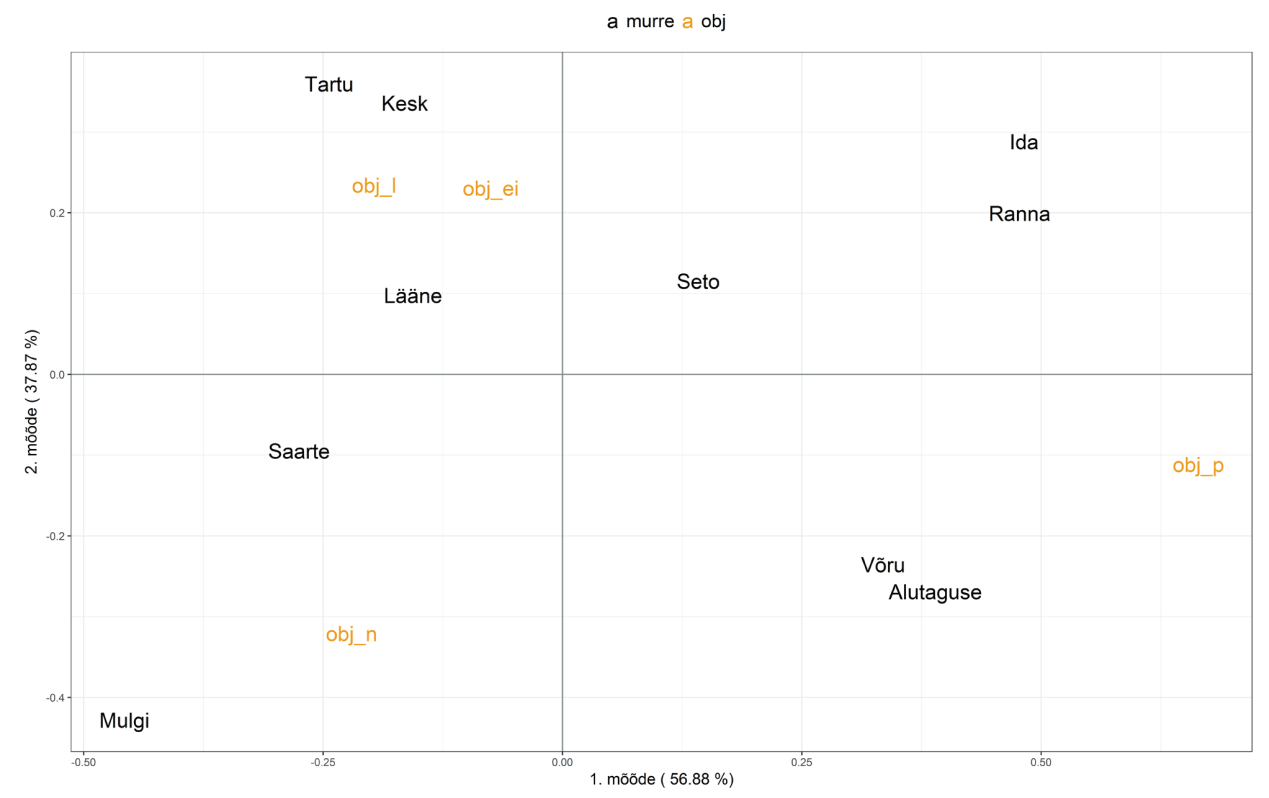

Joonis 4. Lihtne korrespondentsanalü̈̈s objektargumendi vormi ja väljajätu ning murde suhetest.

kaasneb sagedamini osastavas käändes objekt kui muul viisil markeeritud komplemendiga, ja seda just idapoolsemates murretes. Üllatuslikult ei mõjuta verbi lekseem objekti vormi; see tähendab, et kõigi vaadeldavate verbidega toimub objekti käände valik sarnaselt.

\subsection{Komplemendi vormi varieerumine}

Järgnevalt vaatleme, millest sõltub komplemendi vormi varieerumine. Ka see analüüs on läbi viidud kahel viisil: esmalt vaadeldakse vaid komplemendi vormi (saav kääne, nimetav kääne, (ase)määrsõna või muu), seejärel kaasatakse analüüsi ka ilma komplemendita kasutusjuhtumid.

Jooniselt 5 on näha, et erinevalt objekti vormist ei sõltu komplemendi vorm (juhul, kui komplement on väljendatud) primaarselt murdealast, vaid eelkõige objekti vormist. Ehkki mõnevõrra üllatuslikult on nimetav kääne ülekaalukalt kõige sagedasem komplemendi vorm, viidates selgelt suulisusest tulenevale komplemendi nõrgale integreeritusele argumentstruktuuri, esineb nimetavat käänet siiski mõnevõrra vähem ja kirjakeelega sarnaseid vorme (35) rohkem siis, kui objekt on osastavas käändes (Node 2). Ülejäänud objekti vormide puhul 


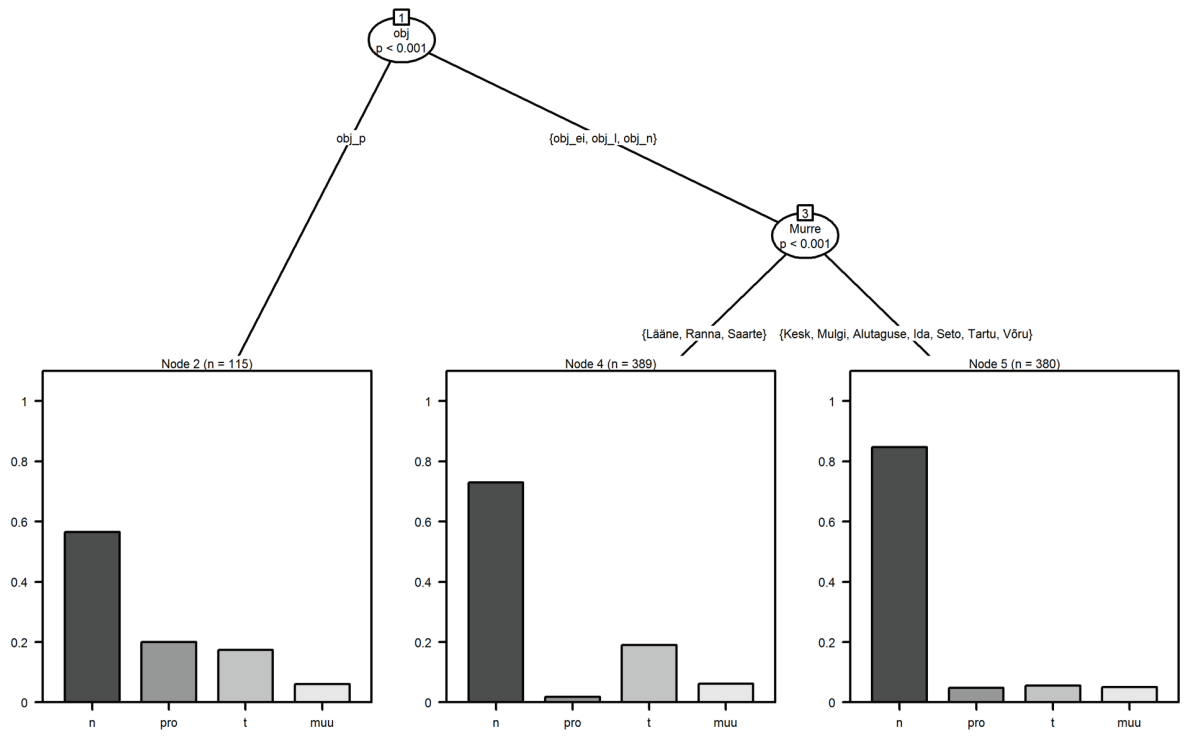

Joonis 5. Komplemendi vormi mõjutavad tegurid klassifitseerimispuus.

(joonisel 5 parem haru) eristub kaks murderühma, mida eristab põhiliselt nimetavas ja saavas käändes olevate komplementide sageduste suhe: lääne-, ranna- ja saarte murde rühmas (Node 4) on võrreldes Alutaguse, ida-, kesk-, Mulgi, Seto, Tartu ja Võru murdega (Node 5, näide 36) proportsionaalselt veidi vähem nimetavas käändes ja veidi enam saavas käändes komplemente (37).

kui (.) ol'l' linanõ (...) tuud [OBJ, p] kutsut't'i rü̈üg [KOMPL, n] (Seto, Lääne-Seto) seda [OBJ, $\mathrm{p}]$ üittakse lemmeks $[\mathrm{KOMPL}, \mathrm{t}]$ (...) rohu lemm (Lääne, Kul)

ruvipeink [KOMPL, n] õigatti sii tü̈̈̈beink [OBJ, n] (Mulgi, Trv) siis oli igal ühel oma seprad (...) ne [OBJ, n] kutsutti seprast [KOMPL, t] (Ranna, VNg)

Klassifitseerimispuu, kuhu on lisatud ka komplemendi väljajätt (joonis 6), hargneb suuresti samamoodi nagu väljajättu mitte arvestav puu, lisandub vaid veel üks hargnemine, kus Alutaguse ja Mulgi murdes on komplemendi väljajätt mittekirjakeelsete objekti vormidega (38) pisut sagedasem kui ida-, kesk-, Seto, Tartu ja Võru murdes. On aga näha, et võrreldes objekti väljajätuga, mis on murrete nimetamiskonstruktsioonides väga üldine, on komplemendi 


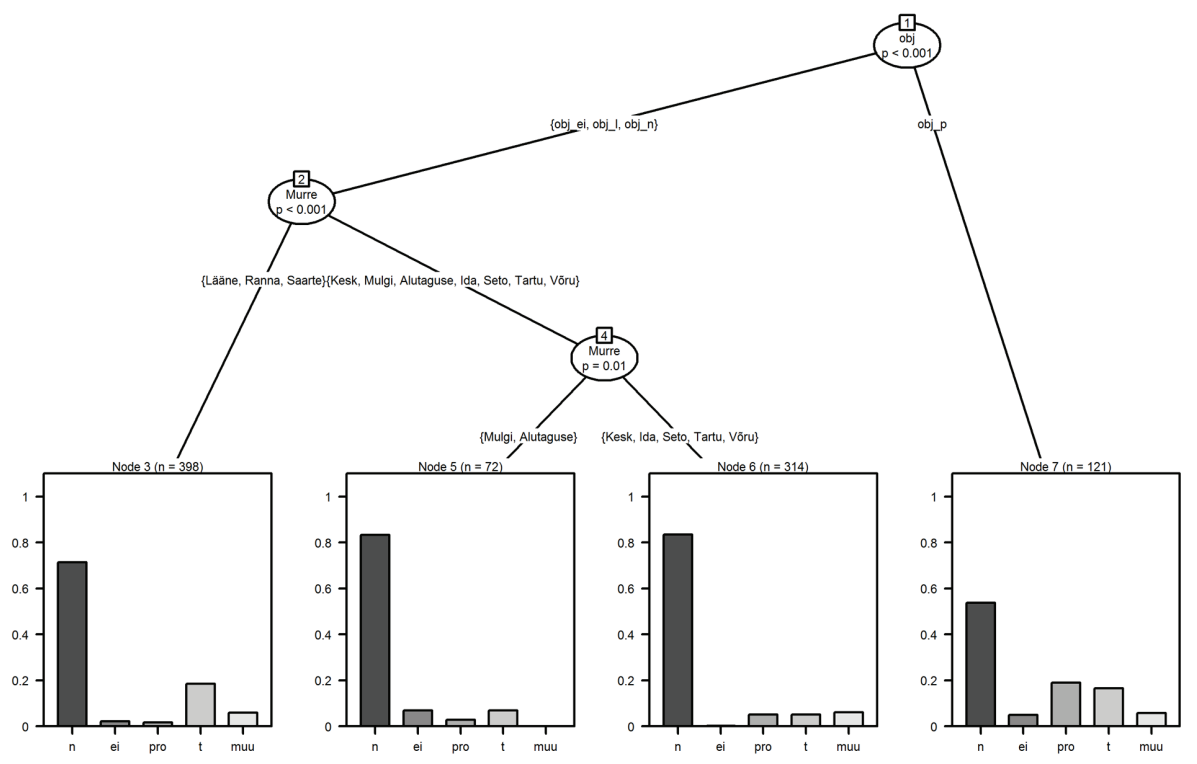

Joonis 6. Komplemendi vormi ja väljajättu mõjutavad tegurid klassifitseerimispuus.

väljendamata jätmine pigem haruldane ning komplemendi vormina domineerib selgelt nimetav kääne.

(38) nee [OBJ, n] kutsutti (.) nohh (.) ma = i mõista tall nime misukkest (Mulgi, Hel)

Klassifitseerimispuude analüüsi täiendavad korrespondentsanalüüsi graafikud. Joonisel 7 on kujutatud komplemendi vormi ja objekti vormi omavahelisi suhteid. Nagu näha, paikneb osastavas käändes objekt teistest objekti vormidest kaugel. Kuna nimetavas käändes komplement (vorm_n) on kõikide objektidega nii sagedane, paikneb see graafikul peaaegu telgede ristumispunktis. See tähendab, et nimetavas käändes komplement kahemõõtmelises ja ainult kahe tunnusega analüüsis (erinevalt klassifitseerimispuu analüüsist, kuhu on kaasatud rohkem seletavaid tunnuseid ja tunnuste-vahelisi interaktsioone) objekti vormi oluliselt ei mõjuta. Kuna teised komplemendi vormid esinevad andmestikus aga võrdlemisi harva, võib graafiku põhjal ning klassifitseerimispuude tulemusi arvestades mõningase ettevaatusega järeldada, et osastavas käändes objekt (obj_p) on veidi tugevamini seotud (ase)määrsõnalise ja saavas käändes komplemendiga (seda kutsuti niimoodi/selleks), nimetavas käändes objekt (obj_n) saavas või nimetavas käändes komplemendiga (see kutsuti see/selleks), 


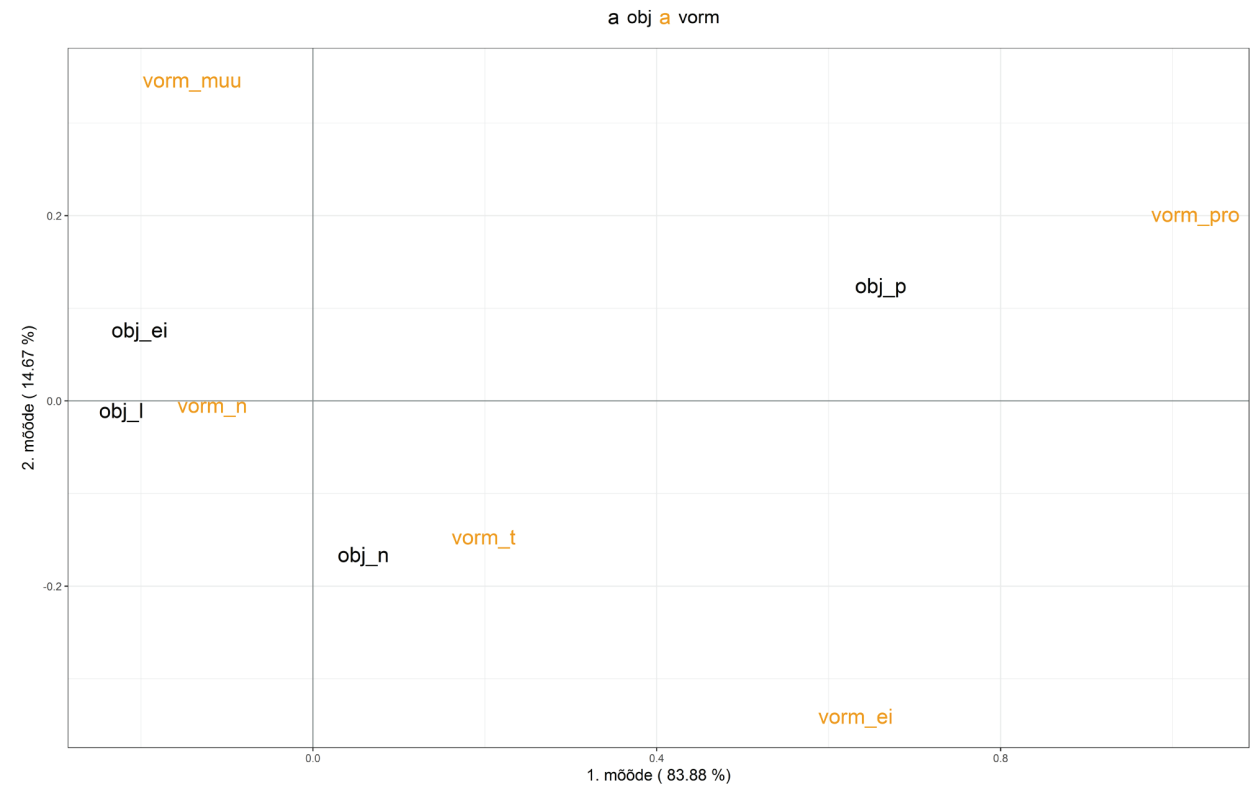

Joonis 7. Lihtne korrespondentsanalüüs komplemendi vormi ja objektargumendi vormi suhetest.

lauseline objekt (obj_l) ja objekti väljajätt (obj_ei) esinevad kõigi komplemendi vormidega, ent seostuvad veidi tugevamalt siiski nimetavas käändes komplemendiga (kes niisugune oli hü̈̈ti see). Komplemendi väljajätt (vorm_ei) või mingil muul moel väljendamine (vorm_muи) on perifeersed nähtused ning paiknevad seepärast graafiku servades, tekitades põhilise osa teisest mõõtmest. Ka üldsageduste põhjal koostatud tabelis 4 on kõige sagedasemad nimetavalise komplemendi (tabelis 4 vorm_n) kombinatsioonid objekti ellipsi (366 korral) ja nimetavas käändes objektiga (220 korral), ning oluliselt harvem osastavas käändes objektiga (65 korral). Saavas käändes komplement (vorm_t) seostub üldsageduse põhjal samade objekti markeerimise viisidega, ehkki üldiselt on saavas käändes komplementi oluliselt vähem kui nimetavalist. Tabeli 4 (ja eelneva analüüsi) põhjal võib öelda, et kui välja jätta lause, kus objekti ei olnud eksplitsiitselt väljendatud, on kõige sagedasem mall nimetavaline objekt - nimetavaline komplement (7).

(7) ning igast puust 'tehti neid `väiksid `pappu (...) nee [OBJ, n] $\underline{\text { kutsutti }}=$ sis kippud $[\mathrm{KOMPL}, \mathrm{n}]$ 'ikke (Saarte, Ans) 
Tabel 4. Komplemendi ja objekti vormistuse lihtsagedusandmed.

\begin{tabular}{|l|l|l|l|l|}
\hline komplement/objekt & obj_ei & obj_l & obj_n & obj_p \\
\hline vorm_n & $\mathbf{3 6 6}$ & 20 & $\mathbf{2 2 0}$ & 65 \\
\hline vorm_ei & 3 & 1 & 11 & 6 \\
\hline vorm_pro & 10 & 0 & 15 & 23 \\
\hline vorm_t & 45 & 2 & 48 & 20 \\
\hline vorm_muu & 33 & 2 & 8 & 7 \\
\hline
\end{tabular}

Nimetavas käändes komplemendi domineerimine osutab, et murdetekstides on valdav komplemendi vähene integreeritus: komplement esineb lauses tsitaadina ega ole argumentstruktuuri kinnistunud. Seda võib pidada üldiseks suulisele kõnele iseloomulikuks jooneks. Teisalt võib selline sage kasutusmall mõjutada konstruktsiooni arengut nimetavas käändes komplemendi kinnistumise suunas. Kasutuspõhises keeleuurimises on välja toodud, et sagedased kasutusviisid mõjutavad keele struktuuri kujunemist (vt nt Bybee 2010; Bybee \& Beckner 2010). Käesoleval juhul domineerib nimetavaline komplement teiste variantide üle suurelt, seega võiks oletada nimetava käände kinnistumist konstruktsiooni, ilma et tajuksime selles tsiteerimist või lõtva seotust konstruktsiooniga. Tänapäeva eesti keele põhjal teame siiski, et nimetav ei ole komplemendi käändena nimetamiskonstruktsioonis levinud ei suulises ega kirjalikus keelekasutuses, seega suund nimetava käände kinnistumisele argumentstruktuuri ei ole kas üldse aset leidnud või on kirjakeelele omane komplemendi markeerimine translatiiviga selle algmeid pidurdanud. Võib oletada, et keelekasutuse kirjaliku kanali järjest laieneva leviku tõttu omandas nimetav kääne üha enam integreerimata tsiteeringu värvingut ja jäi seetõttu kirjakeelde sobimatuna laiemast kasutusest välja.

Ei saa jätta märkimata, et kombinatsiooni nimetavaline objekt - nimetavaline komplement sagedast kasutamist murdekorpuse tekstides võib olla mõjutanud ka asjaolu, et nimetamiskonstruktsioon on sisult sarnane predikatiivlausega, vrd see on Hobusekivi (predikatiivkonstruktsioon) - see kutsuti Hobusekivi (nimetamiskonstruktsioon). Sellisel juhul toimib nimetamist tähistav verb analoogia mõjul lihtsa koopulana ning nimetamiskonstruktsioon järgib predikatiivkonstruktsiooni malli.

Kuna klassifitseerimispuus avaldus madalamates hargnemistes ka murdealade mõju, vaatleme põgusalt ka murrete ja komplemendi vormi suhteid korrespondentsanalüüsi graafikul (joonis 8).

Esimese mõõtme paistavad tekitavat nimetavas käändes komplement (vorm_n), mis oli ka üldiselt kõige sagedasem komplemendi markeerimise viis, vs. ülejäänud komplemendi vormid. Alutaguse, Mulgi, Seto ja Tartu murre näivad seostuvat pigem nimetavas käändes komplemendiga, samas kui ranna- 


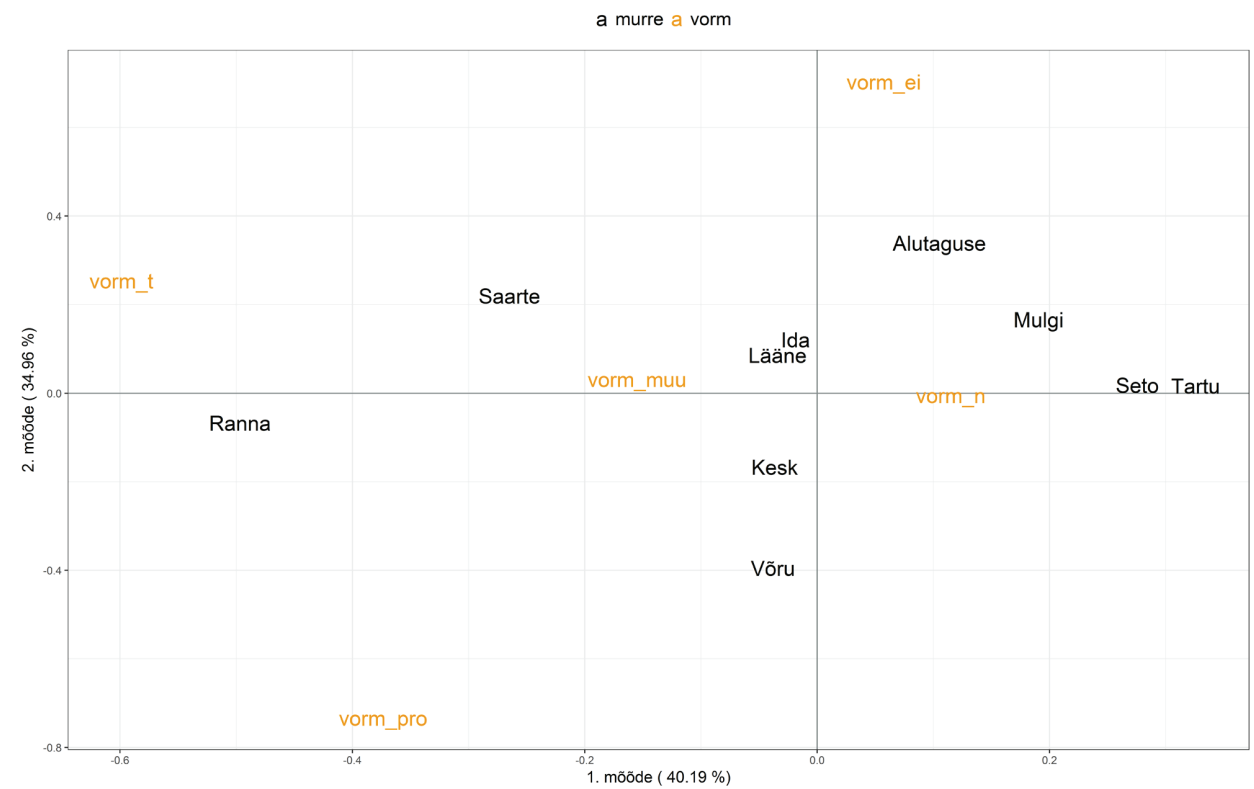

Joonis 8. Lihtne korrespondentsanalü̈̈s komplemendi vormi ja väljajätu ning murrete suhetest

ja saarte murre eelistavad pigem saavat käänet (vorm_t), rannamurre ka (ase)määrsõnalisi komplemente (vorm_pro). Nende vahele jäävad ida-, lääne, kesk- ja Võru murre, mille komplemendi vormid näivad rohkem varieeruvat. Komplemendi väljajätt (vorm_ei) on harv ning seostub mõnevõrra tugevamalt Alutaguse ja Mulgi murdega, nagu ilmnes ka klassifitseerimispuus.

Pandagu aga tähele, et komplemendi vormi ja murdeala vahel seletavad esimesed kaks mõõdet kokku vaid $75 \%$ ridade ja veergude korrelatsioonist, samas kui vormi ja objekti vahelisel graafikul on kahe mõõtmega seletatud peaaegu kogu variatsioon $(98,55 \%)$. See tähendab, et vormi varieerumise puhul on tervelt $25 \%$ vastustest peidus kuskil mujal ega pruugi olla otseselt seotud murdealaga.

\subsection{Verbilekseemi valik}

Järgnevalt vaatleme, millest sõltub verbi valik konstruktsioonis. Nagu eespool mainitud, on analüüsi kaasatud lekseemid kutsuma (joonisel $9 \mathrm{~K}$ ), nimetama $(N)$, hüüdma $(H)$ ja hõikama (Hõ). Analüüsist jäi välja verb ütlema, sest selle kasutussagedus nimetamiskonstruktsioonis oli kvantitatiivse analüüsi jaoks liiga madal (vaid 11 kasutusjuhtu). 


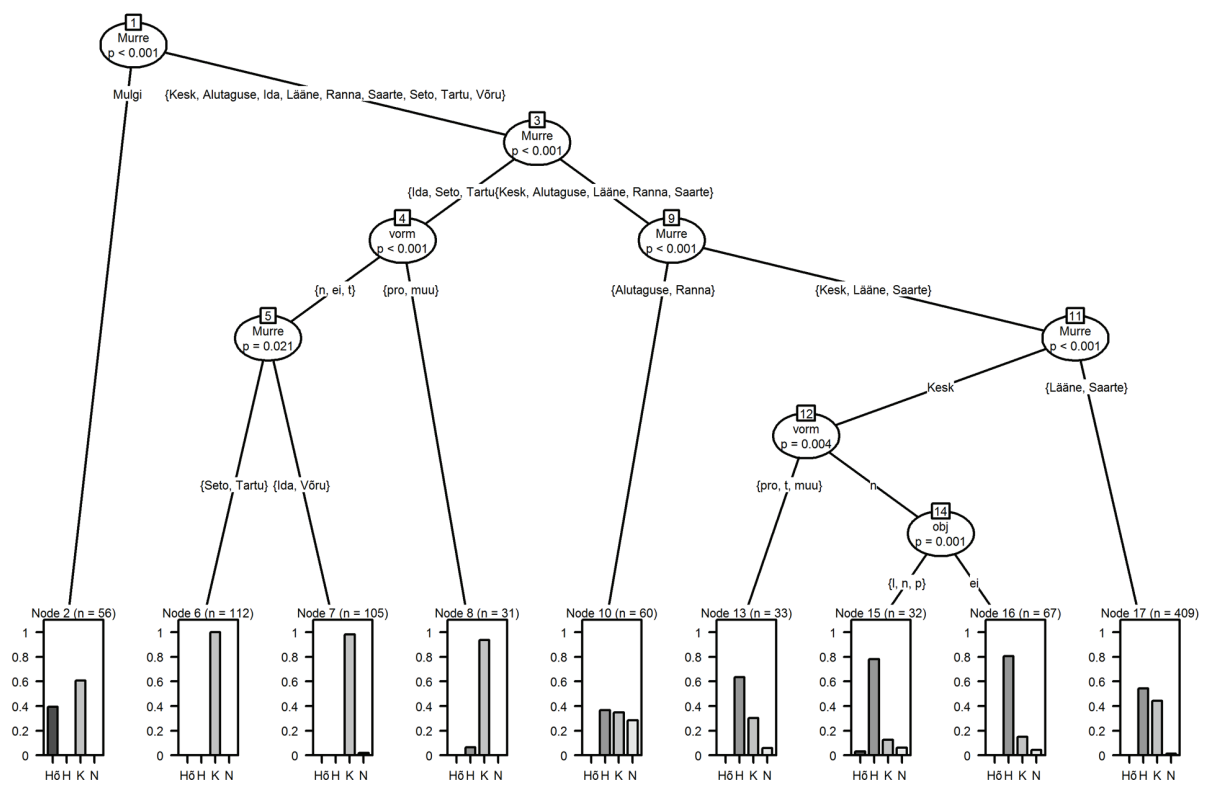

Joonis 9. Verbilekseemi valikut mõjutavad tegurid klassifitseerimispuus.

Klassifitseerimispuu, mis analüüsib verbilekseemi valikut mõjutavaid tegureid (joonis 9), näitab selgelt, et konstruktsioonis esineva lekseemi valiku määrab esmajoones murdeala või -rühm. Hõikama on verb, mis esineb nimetamiskonstruktsiooni osana peaaegu eranditult vaid Mulgi murdes; joonisel osutab seda esmane jagunemine klassifitseerimispuus, mis eristab Mulgi murde muudest. Teine jagunemine (Node 3) moodustab kaks murderühma, mida eristab vastavalt verbi kutsuma või hü̈̈dma eelistamine konstruktsioonis. Ehkki kutsuma on levinud kõikides murretes, eelistatakse seda kindlalt kõikidele teistele idamurdes ning lõunaeesti murretes, samas kui enamikus põhjaeesti murretes esineb konstruktsioonis sagedamini verb hü̈̈dma. See kinnitab osaliselt ka "Väikese murdesõnastiku" levikuandmeid, ehkki nagu öeldud, on meie materjalis ainult nimetamiskonstruktsioonis esinevad tähendused, samas kui sõnaraamatus lekseemi kasutuskonteksti ei täpsustata (v.a verbi nimetama puhul). Omaette murderühma moodustavad nimetamiskonstruktsioonide verbilekseemi valiku põhjal kirderanniku murded ehk Alutaguse ja rannamurre, mille nimetamiskonstruktsioonides on verbide hü̈̈dma ja kutsuma kõrval enam-vähem sama sage ka verb nimetama. Ülejäänud põhjaeesti murretest eristub keskmurre, mille nimetamiskonstruktsioonides esinevad kõik neli verbi, ehkki verb hõika$m a$ on seal väga harv ning hü̈̈dma on proportsionaalselt oluliselt sagedasem 


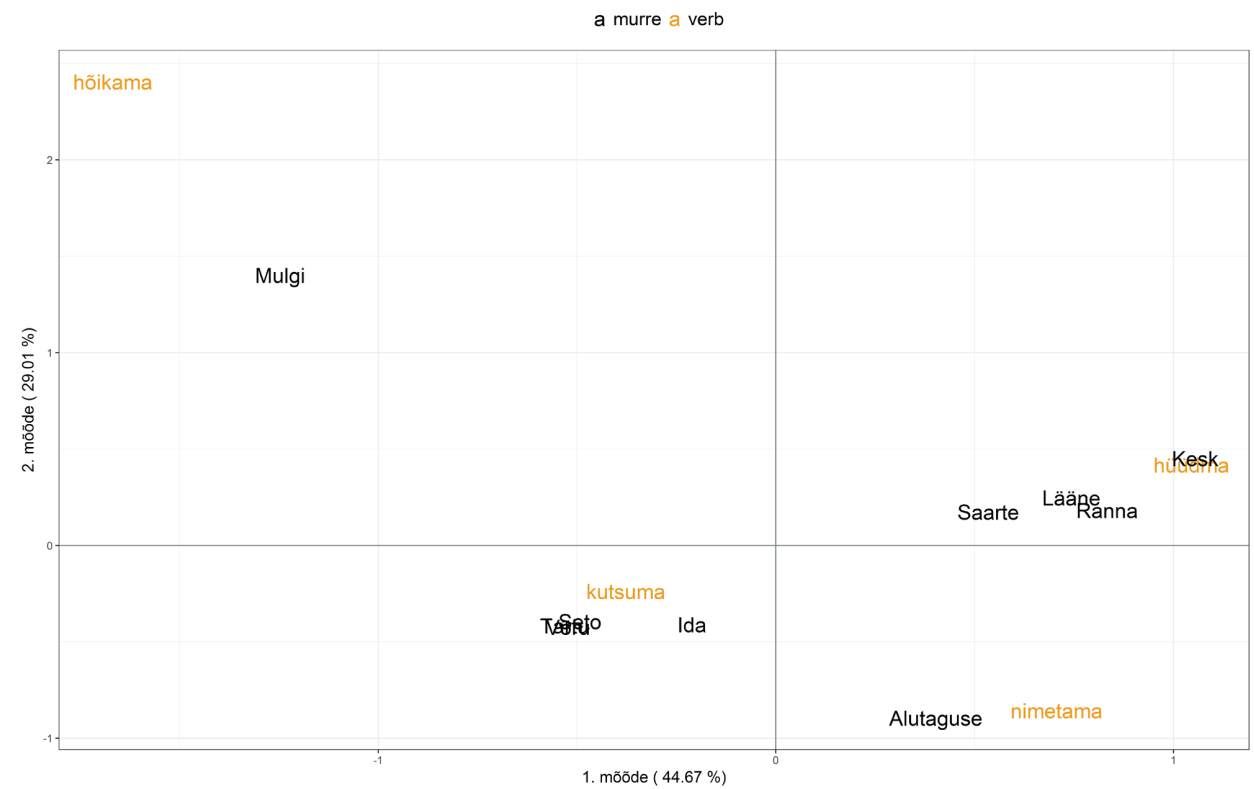

Joonis 10. Lihtne korrespondentsanalüüs verbilekseemide ja murrete suhetest.

kui teistes murretes. Hü̈̈dma-verbi kasutamist keskmurdes näib eriti soosivat komplemendi nõrk integreeritus ehk nimetava käände kasutamine (Node 14).

Ka korrespondentsanalüüsi graafik (joonis 10) kinnitab, et nimetamiskonstruktsioonide finiitse verbi valik on selgelt areaalselt määratud. Hõikama on andmestikus harv ning seostub põhiliselt Mulgi murdega. Kutsuma on võrdlemisi sage kõikjal, ent prevaleerib selgelt lõunaeesti murretes ja idamurdes, samas kui põhjaeesti murretes (v.a idamurre) on levinum verb hüüdma. Nimetama on samuti andmestikus üsna harv ja seostub siin eelkõige Alutaguse murdega. Ehkki ka selles analüüsis seletavad graafikul esitatud kaks esimest dimensiooni vaid $73,68 \%$ verbilekseemide ja murrete vahelisest korrelatsioonist, tuleneb eelnevatest graafikutest madalam protsent sedapuhku sellest, et Mulgi murre ja hõikama-verb on omavahel väga tugevalt seotud, ent esinemissageduselt teistega võrdluses siiski harv kombinatsioon. Seetõttu seletaks verbilekseemide ja murrete seoseid kõige paremini hoopis kolmedimensiooniline graafik, millel hõikama-verb ja Mulgi murre paikneksid ruumiliselt teistest klastritest oluliselt eespool.

Kokkuvõttes võib öelda, et leksikaalne varieerumine konstruktsioonis on üpris selgelt murdeliselt määratletud ning komplemendi vorm või objekti vorm verbilekseemi valikut oluliselt ei mõjuta. 


\section{Kokkuvõte}

Artiklis vaatlesime nimetamiskonstruktsiooni varieerumist eesti murretes eesmärgiga välja selgitada, kas konstruktsiooni eri osade varieerumist mõjutavad enim areaalsed ehk murdeerinevused või konstruktsioonisisesed faktorid, mis võivad omakorda olla tingitud suulisest suhtluskanalist. Kaht kvantitatiivset meetodit - klassifitseerimispuud ja korrespondentsanalüüsi - kombineerides leidsime, et üllatavalt suur osa varieerumisest on siiski taandatav murdelisele varieerumisele.

Kõige selgemalt avaldusid murdeerinevused leksikaalses varieerumises, s.t verbilekseemi valikus. Kutsuma on nimetamiskonstruktsioonis kasutusel eelkõige lõunaeesti murretes (Tartu, Võru, Seto murre) ja nendega vahetult külgnevas idamurdes. Hü̈̈dma on iseloomulik põhjaeesti murderühmale (keskmurre, saarte murre, läänemurre) ja rannamurdele. Hõikama on seotud peaaegu eranditult Mulgi murdega. Nimetama on tugevalt seotud Alutaguse murdega. Miks selline leksikaalne jaotumine on toimunud, on raske seletada ning vajab ilmselt põhjalikumat etümoloogilist ja keelekontaktide käsitlust. On võimalik, et vähemalt osaliselt on lekseemi valik mõjutatud kontaktkeelte vastava konstruktsiooni verbilekseemist (näiteks tarvis/vaja-konstruktsioonides olid paralleelid naaberkeeltega väga ilmsed, vt Lindström et al. 2014).

Ka objekti vormi valikul osutus kõige olulisemaks teguriks murdeala: nimetavas käändes objekt oli sagedasem põhjas, läänes ja edelas, osastavas käändes objekt aga idas, kirdes ja kagus. See kinnitab oletust, mille järgi konstruktsioonides/kontekstides, kus nimetava/osastava (või totaalse/partsiaalse) vastandus ei ole semantiliselt oluline, kaldub läänepoolsemates eesti murretes nimetav kääne osastava funktsioone üle võtma (vt ka Lindström 2017). Murderühmade sees mängivad omakorda rolli murrete ja komplemendi vormi koosmõjud.

Vaatlesime põgusalt ka objekti väljajättu ja selle seost murdealaga, ent ilmset seost siin ei olnud. See kinnitab, et argumendi väljajätt on seotud pigem konteksti ja infostruktuuriga (ja laiemalt teksti/diskursusega), mitte niivõrd murdealaga, ning on seletatav pigem universaalse suhtlusprintsiibiga, mille kohaselt ennustatavat infot pole tarvis eraldi välja tuua (Givón 2017: 3).

Murdeerinevused osutusid vähem oluliseks komplemendi vormi valikul. Komplemendi vormi mõjutasid pigem konstruktsioonisisesed tegurid, eelkõige objekti kääne. Ehkki igal juhul domineerib nimetavas käändes komplement, on osastavalise objekti puhul saavas käändes komplemendi osakaal mõnevõrra suurem. See viitab sellele, et osastava käändega markeeritud objekti puhul on komplement integreeritud verbi argumentstruktuuri tugevamalt kui siis, kui objekt on mingis muus vormis. Komplemendi väljajätt on võrdlemisi harv (seostub eelkõige eneseparanduste ja kõne planeerimise probleemidega). Ka 
see on ootuspärane: komplement on nimetamiskonstruktsioonis see osaline, mis esitab kõige olulisemat uut infot, s.t seda, kuidas mingit (juba mainitud) objekti nimetatakse. Kõige olulisema uue info väljajätt on võimalik vaid mingil moel erandlike lausete puhul (nagu eneseparandused seda on).

Üldsageduse põhjal domineerib murdematerjalis selgelt nimetavas käändes komplement, mis seostub kõige tugevamalt objekti väljajätu ja nimetavas käändes objektiga. Nimetavas käändes komplemendi domineerimine on ilmselt seotud suulisusega: komplement on tüüpiliselt ühesõnaline tsiteering ning on seetõttu lausesse nõrgalt integreeritud.

Kuigi materjali esmasel vaatlusel tundus, et sidendi et kasutamine konstruktsioonis on üsna selgelt iseloomulik Võru murdele (näide 9), ei osutunud sidendi olemasolu lauses huvitaval kombel oluliseks üheski analüüsis. Seda tõenäoliselt peamiselt seetõttu, et see oli kogu materjalis väga harv ega tõusnud seetõttu kvantitatiivses analüüsis esile.

Kokkuvõtteks võib öelda, et ehkki esmasel vaatlusel tundus, et nimetamiskonstruktsioonide varieerumises ei ole olulisi murdeerinevusi, on andmestiku kvantitatiivsel analüüsil ilmsed siiski mõningad regionaalsed tendentsid. Seejuures vaid leksikaalne varieerumine järgib enam-vähem klassikalist lõunapõhja eristust (mis põhineb foneetilistel, morfoloogilistel ja leksikaalsetel joontel). Objekti käände valikul näib olulisem olevat ida- ja läänepoolsete murrete vaheline eristus, mis on süntaksialastest töödest välja tulnud varemgi (Uiboaed 2013; Uiboaed et al. 2013; Lindström et al. 2014; Lindström et al. 2015). Siiski on vaadeldavates konstruktsioonides suur osa varieerumisest selline, mis on pigem seotud konstruktsiooni teise osa või hoopis millegi muuga, näiteks suulisusega. Eelkõige seostub suulisusega nimetavas käändes komplemendi kasutamine tsiteeritud osa edasiandmiseks (nt See kutsuti Hobusekivi. Kutsuti Hobusekivi.), mis materjalis oli ülivaldav.

Artiklis ei vaadeldud siiski kõiki võimalikke tegureid, mis võiksid varieerumist selgitada. Sestap tasub tulevikus uurida näiteks seda, kuivõrd mõjutab konstruktsiooni osade varieerumist (eelkõige objektargumendi ja komplemendi vormi) sõnajärg, s.t komplemendi ja objekti paiknemine finiitverbi suhtes, ning infostruktuurilised printsiibid, mis mõjutavad kindlasti ka argumentide väljajättu. 


\section{Kommentaarid}

1 Artikkel on valminud Euroopa Liidu Regionaalarengu Fondi toel (Eesti-uuringute Tippkeskus).

${ }^{2}$ Kõik näited on esitatud sellisel kujul, nagu nad allikates esinevad. Näited, mille puhul allikat ei ole täpsustatud, pärinevad murdekorpusest ning nendes on kasutatud murdekorpuse lihtsustatud transkriptsiooni, kus = märgib kokkuhääldust, ‘ kolmandat väldet, * kolmveerandpikkust, ' palatalisatsiooni, (.) ja (...) pause (vt lähemalt https://www.keel.ut.ee/sites/default/files/www_ut/emk_teejuht2015.pdf). Näidete lõpus olevate kihelkondade lühendite selgitused leiab Eesti Keele Instituudi kihelkondade loendist leheküljel http://www.eki.ee/dict/vms/vmssubst.html. Kihelkondade kaardi võib leida Regio leheküljelt http://www.regio.ee/?op=news\&id=116.

3 Vt murdekorpuse materjalide kogumispunkte: http://www.keel.ut.ee/et/murdekorpusehetkeseis (2. jaanuar 2018).

${ }^{4}$ Node märgib joonistel puu igat sõlme või tippu, millest hargnemine algab, jätkub või kus hargnemine peatub.

\section{Kirjandus}

Amon, Marri 2015. Initial and final detachments in spoken Estonian: a study in the framework of Information Structuring. Dissertationes linguisticae Universitatis Tartuensis 24. Tartu: Tartu Ülikooli Kirjastus (http://dspace.ut.ee/handle/10062/47495 8. jaanuar 2018).

Arppe, Antti \& Gilquin, Gaëtanelle \& Glynn, Dylan \& Hilpert, Martin \& Zeschel, Arne 2010. Cognitive Corpus Linguistics: five points of debate on current theory and methodology. Corpora 5 (1), lk 1-27 (doi: 10.3366/cor.2010.0001).

Auer, Peter 2009. On-line syntax: Thoughts on the temporality of spoken language. Language Sciences 31(1), lk 1-13 (doi: 10.1016/j.langsci.2007.10.004).

Baayen, Harald R. 2008. Analyzing linguistic data: A practical introduction to statistics using $R$. Cambridge: Cambridge University Press.

Barlow, Michael \& Kemmer, Suzanne (toim) 2000. Usage Based Models of Language. Stanford: CSLI Publications.

Breiman, Leo \& Friedman, Jerome \& Stone, Charles J. \& Olshen, Richard A. 1984. Classification and Regression Trees. New York: Chapman and Hall.

Bybee, Joan 2010. Language, usage and cognition. Cambridge University Press (doi: 10.1017/CBO9780511750526).

Bybee, Joan \& Beckner, Clay 2010. Usage-based theory. Heine, Bernd \& Narrog, Heike (toim). The Oxford Handbook of Linguistic Analysis. Oxford: University Press, lk 827-855 (doi: 10.1093/oxfordhb/9780199544004.013.0032).

Croft, William 2001. Radical construction grammar: syntactic theory in typological perspective. Oxford Linguistics. Oxford: Oxford University Press. 
Divjak, Dagmar \& Gries, Stefan Th. (toim) 2012. Frequency effects in language representation. Berlin: De Gruyter.

EKG II = Erelt, Mati \& Kasik, Reet \& Metslang, Helle \& Rajandi, Henno \& Ross, Kristiina \& Saari, Henn \& Tael, Kaja \& Vare, Silvi 1993. Eesti keele grammatika II. Süntaks. Lisa: Kiri. Tallinn: Eesti Teaduste Akadeemia Keele ja Kirjanduse Instituut. EKKS = Eesti kirjakeele seletav sõnaraamat (https://www.eki.ee/dict/ekss/ - 8. jaanuar 2018).

EMS IV = Haak, Anu \& Juhkam, Evi \& Kask, Ann \& Must, Mari \& Nigol, Salme \& Niit, Ellen \& Oja, Vilja \& Ross, Eevi \& Sepp, Aldi \& Univere, Aili \& Viires, Helmi (koost) 2004. Eesti murrete sõnaraamat, IV köide, 16. vihik (kuma-kõhvima). Tallinn: Eesti Keele Sihtasutus.

EMS VI = Kalvik, Mari-Liis \& Kendla, Mari \& Laansalu, Tiina (toim). Eesti murrete sõnaraamat, VI köide, 28. vihik (mütsatama-nisu). 2017. Tallinn: Eesti Keele Instituut.

Erelt, Mati 2017. Liitlause. Erelt, Mati \& Metslang, Helle (toim). Eesti keele süntaks. Tartu: Tartu Ülikooli Kirjastus, lk 647-755.

Ermus, Liis \& Kalvik, Mari-Liis \& Laansalu, Tiina (ilmumas). The Archive of Estonian Dialects and Finno-Ugric Languages at the Institute of the Estonian Language. Björklöf, Sofia \& Jantunen, Santra (toim). Plurilingual Finnic. Change of Finnic languages in a multilinguistic environment. Uralica Helsingiensia 11. Helsinki: Finno-Ugrian Society.

Givón, Talmy 2017. The Story of Zero. Amsterdam/Philadelphia: John Benjamins Publishing Company (doi: 10.1075/z.204).

Glynn, Dylan 2014. Correspondence analysis: Exploring data and identifying patterns. Glynn, Dylan \& Robinson, Justyna A. (toim). Corpus Methods for Semantics: Quantitative studies in polysemy and synonymy. Amsterdam/Philadelphia: John Benjamins Publishing Company, lk 443-486 (doi: 10.1075/hcp.43.17gly).

Goldberg, Adele E. 1995. Constructions: A Construction Grammar Approach to Argument Structure. Chicago: University of Chicago Press.

Greenacre, Michael 2006. From Simple to Multiple Correspondence Analysis. Greenacre; Michael \& Blasius, Jörg (toim). Multiple Correspondence Analysis and Related Methods. London: Chapman \& Hall, lk 41-76 (doi: 10.1201/9781420011319.ch2).

Greenacre, Michael 2007. Correspondence Analysis in Practice. London: Chapman \& Hall. Gries, Stefan Th. \& Divjak, Dagmar (toim) 2012. Frequency effects in language learning and processing. Berlin: De Gruyter.

Heine, Bernd \& Kuteva, Tania 2005. Language Contact and Grammatical Change. Cambridge: Cambridge University Press.

Hennoste, Tiit 2000. Sissejuhatus suulisesse eesti keelde I-VIII. Akadeemia 5-12, nr 5 lk 1117-1150, nr 6 lk 1341-1374, nr 7 lk 1551-1582, nr 8 lk 1772-1806, nr 9 lk 2009_ 2038, nr 10 lk 2221-2254, nr 11 lk 2463-2486, nr 12 lk 2687-2710.

Hennoste, Tiit 2001. Sissejuhatus suulisesse eesti keelde IX. Lausung suulises kõnes 4. Akadeemia 1, lk 179-206. 
Hennoste, Tiit 2004. Et-komplementlause peaverbide funktsioonid eestikeelses vestluses. Keel ja Kirjandus nr 7 lk 504-523, nr 8 lk 590-609.

Hennoste, Tiit 2013. Grammatiliste vormide seoseid suhtlustegevustega eestikeelses suulises vestluses. Dissertationes Philologiae Estonicae Universitatis Tartuensis 32. Tartu: Tartu Ülikooli Kirjastus (http://dspace.ut.ee/bitstream/handle/10062/28923/ hennoste_tiit.pdf?sequence=1 - 8. jaanuar 2018).

Hilpert, Martin 2013. Corpus-based approaches to constructional change. Hoffmann,Thomas \& Trousdale, Graeme (toim). The Oxford Handbook of Construction Grammar. Oxford: Oxford University Press, lk 458-475 (doi: 10.1093/oxfordhb/9780195396683.013.0025).

Hothorn, Torsten \& Hornik, Kurt \& Zeileis, Achim 2006. Unbiased recursive partitioning: A conditional inference framework. Journal of Computational and Graphical Statistics 15 (3), lk 651-674 (doi: 10.1198/106186006X133933).

Kask, Arnold 1984. Eesti murded ja kirjakeel. Eesti NSV Teaduste Akadeemia Emakeele Seltsi toimetised 16. Tallinn: Valgus.

Klavan, Jane \& Pilvik, Maarja-Liisa \& Uiboaed, Kristel 2015. The Use of Multivariate Statistical Classification Models for Predicting Constructional Choice in Spoken, NonStandard Varieties of Estonian. SKY Journal of Linguistics 28, lk 187-224 (http://www. linguistics.fi/julkaisut/SKY2015/SKYJoL28_Klavan.pdf - 8. jaanuar 2018).

Koptjevskaja-Tamm, Maria \& Wälchli, Bernhard 2001. The Circum-Baltic Languages: An Areal-Typological Approach. Dahl, Östen \& Koptjevskaja-Tamm, Maria (toim). Circum-Baltic Languages: Typology and Contact. Volume 2: Grammar and Typology. Studies in Language Companion Series (SLCS) 55. Amsterdam, Philadelphia: Benjamins, lk 615-750.

Kortmann, Bernd 2010. Areal variation in syntax. Auer, Peter \& Schmidt, Jürgen E. (toim). Language and Space: An International Handbook of Linguistic Variation. Theories and Methods. Berlin/New York: Mouton de Gruyter, lk 837-864.

Lindström, Liina 2001. Eesti murrete korpuse iseloomustus argivestlusega võrrelduna. Kasik, Reet (toim). Keele kannul. Pühendusteos Mati Erelti 60. sünnipäevaks 12. märtsil 2001. Tartu Ülikooli Eesti Keele Õppetooli Toimetised 17. Tartu: Tartu Ülikooli Kirjastus, lk 212-221.

Lindström, Liina 2005. Finiitverbi asend lauses. Sõnajärg ja seda mõjutavad tegurid suulises eesti keeles. Dissertationes Philologiae Estonicae Universitatis Tartuensis 16. Tartu: Tartu Ülikooli Kirjastus (http://hdl.handle.net/10062/924 - 8. jaanuar 2018).

Lindström, Liina 2015. Ülevaade eesti murrete korpusest seisuga 17.11.2015 (http:// www.keel.ut.ee/sites/default/files/www_ut/emk_teejuht2015.pdf - 8. jaanuar 2018).

Lindström, Liina 2017. Partitive subjects in Estonian dialects. Eesti ja Soome-ugri Keeleteaduse Ajakiri / Journal of Estonian and Finno-Ugric Linguistics 8 (2), lk 191-231 (doi: 10.12697/jeful.2017.8.2.07).

Lindström, Liina \& Vihman, Virve-Anneli 2017. Who Needs It? Variation in experiencer marking in Estonian “need”-constructions. Journal of Linguistics 53 (4), lk 789-822 (doi: 10.1017/S0022226716000402). 
Lindström, Liina \& Kalmus, Mervi \& Klaus, Anneliis \& Bakhoff, Liisi \& Pajusalu, Karl 2009. Ainsuse 1. isikule viitamine eesti murretes. Emakeele Seltsi aastaraamat 54, lk 159-185.

Lindström, Liina \& Uiboaed, Kristel \& Vihman, Virve-Anneli 2014. Varieerumine tarvis-/ vaja-konstruktsioonides keelekontaktide valguses. Keel ja Kirjandus 8-9, lk 609-630 (http://kjk.eki.ee/pdf/LindstromUiboaedVihman609_630.pdf - 8. jaanuar 2018).

Lindström, Liina \& Uiboaed, Kristel 2017. Syntactic variation in 'need'-constructions in Estonian dialects. Nordic Journal of Linguistics 40 (3), lk 313-349 (doi: 10.1017/ S0332586517000191).

Lindström, Liina \& Pilvik, Maarja-Liisa \& Ruutma, Mirjam \& Uiboaed, Kristel 2015. Mineviku liitaegade kasutusest eesti murretes keelekontaktide valguses. Võro Instituudi toimõndusõq 29, lk 39-70.

Lindström, Liina \& Pilvik, Maarja-Liisa \& Ruutma, Mirjam \& Uiboaed, Kristel (ilmumas). On the use of perfect and pluperfect in Estonian dialects: frequency and language contacts. Björklöf, Sofia \& Jantunen, Santra (toim). Plurilingual Finnic. Change of Finnic languages in a multilinguistic environment. Uralica Helsingiensia 11. Helsinki: Finno-Ugrian Society.

Lindström, Liina \& Lippus, Pärtel \& Tuisk, Tuuli (ilmumas). The online database of the University of Tartu Archives of Estonian Dialects and Kindred Languages and the Corpus of Estonian Dialects. Björklöf, Sofia \& Jantunen, Santra (toim). Plurilingual Finnic. Change of Finnic languages in a multilinguistic environment. Uralica Helsingiensia 11. Helsinki: Finno-Ugrian Society.

Metslang, Helena 2014. Partitive noun phrases in the Estonian core argument system. Luraghi, Silvia \& Huumo, Tuomas (toim). Partitive Cases and Related Categories. Empirical Approaches to Language Typology 54. Berlin \& New York: Mouton de Gruyter, lk 177-255.

Metslang, Helle 2017. Sihitis. Erelt, Mati \& Metslang, Helle (toim). Eesti keele süntaks. Eesti keele varamu 3. Tartu: Tartu Ülikooli Kirjastus, lk 258-277.

Must, Mari 1987. Kirderannikumurre. Häälikuline ja grammatiline ülevaade. Tallinn: Valgus.

Pajusalu, Karl \& Hennoste, Tiit \& Niit, Ellen \& Päll, Peeter \& Viikberg, Jüri 2009. Eesti murded ja kohanimed. 2., täiendatud trükk. Tallinn: Eesti Keele Sihtasutus.

Pajusalu, Renate 2015. Hidden subjects in conversation: Estonian personless verb forms as referential devices. Helasvuo, Marja-Liisa \& Huumo, Tuomas (toim). Subjects in Constructions - Canonical and Non-Canonical. Constructional Approaches to Language 16. Amsterdam: John Benjamins Publishing Company, lk 43-72 (doi: 10.1075/ cal.16.03paj).

Pilvik, Maarja-Liisa 2016. olema + Vmine konstruktsioonid eesti murretes. Keel ja Kirjandus 6, lk 429-446 (http://kjk.eki.ee/pdf/M-LPilvik_6-16.pdf-10. jaanuar 2018).

Pilvik, Maarja-Liisa 2017. Deverbal -mine action nominals in the Estonian Dialect Corpus. Eesti ja soome-ugri keeleteaduse ajakiri / Journal of Estonian and Finno-Ugric Linguistics 8 (2), lk 295-326 (doi: 10.12697/jeful.2017.8.2.10). 
Plado, Helen 2013. Kausaalsuhete adverbiaallaused eesti kirjakeeles. Dissertationes philologiae Estonicae Universitatis Tartuensis 35. Tartu: Tartu Ülikooli Kirjastus (http:// dspace.ut.ee/handle/10062/34591 - 10. jaanuar 2018).

Plado, Helen 2015. des- ja mata-konverbi kasutusest eesti murretes. Emakeele Seltsi aastaraamat 61 (1), lk 195-218 (doi: 10.3176/esa60.10).

Ruutma, Mirjam \& Kyröläinen, Aki-Juhani \& Pilvik, Maarja-Liisa \& Uiboaed, Kristel 2016. Ambipositsioonide morfosüntaktilise varieerumise kirjeldusi kvantitatiivsete profiilide abil. Keel ja Kirjandus 2, lk 92-113.

Strobl, Carolin \& Malley, James \& Tutz, Gerhard 2009. An introduction to recursive partitioning: Rationale, application, and characteristics of classification and regression trees, bagging, and random forests. Psychological Methods 14 (4), lk 323-348 (doi: 10.1037/a0016973).

Szmrecsanyi, Benedikt 2013. Grammatical variation in British English dialects: a study in corpus-based dialectometry. Cambridge: Cambridge University Press.

Taremaa, Piia 2017. Attention meets language: a corpus study on the expression of motion in Estonian. Dissertationes linguisticae Universitatis Tartuensis 29. Tartu: Tartu Ülikooli Kirjastus (http://dspace.ut.ee/handle/10062/55362 - 10. jaanuar 2018).

Torn-Leesik, Reeli 2009. The voice system of Estonian. STUF: Language Typology and Universals Sprachtypologie und Universalienforschung 62 (1-2), lk 72-90 (doi: 10.1524/ stuf.2009.0005).

Torn-Leesik, Reeli \& Vihman, Virve-Anneli 2010. The Uses of Impersonals in Spoken Estonian. SKY Journal of Linguistics 23, lk 301-343.

Uiboaed, Kristel 2013. Verbiühendid eesti murretes. Dissertationes Philologiae Estonicae Universitatis Tartuensis 34. Tartu: Tartu Ülikooli Kirjastus (http://dspace.ut.ee/ handle/10062/34499 - 10. jaanuar 2018).

Uiboaed, Kristel \& Hasselblatt, Cornelius \& Lindström, Liina \& Muischnek, Kadri \& Nerbonne, John 2013. Variation of verbal constructions in Estonian dialects. Literary \& Linguistic Computing 28 (1), lk 42-62 (doi: 10.1093/llc/fqs053).

VMS = Pall, Valdek (toim) 1996. Väike murdesõnastik (http://www.eki.ee/dict/vms/ 10. jaanuar 2018). 


\section{Summary}

\section{Naming constructions in Estonian dialects: dialectal differences or spoken syntax?}

\section{Liina Lindström}

Associate Professor, Senior Research Fellow in Estonian language

Institute of Estonian and General Linguistics

University of Tartu, Estonia

liina.lindstrom@ut.ee

\section{Maarja-Liisa Pilvik}

Junior Research Fellow in Applied Dialectology, postgraduate student

Institute of Estonian and General Linguistics

University of Tartu, Estonia

maarja-liisa.pilvik@ut.ee

\section{Helen Plado}

Lecturer in Estonian language, Research Fellow in Estonian language

Institute of Estonian and General Linguistics

University of Tartu, Estonia

Research Fellow, Võru Institute, Estonia

helen.plado@ut.ee

Keywords: dialect syntax, Estonian dialects, naming construction, spoken syntax, variation

This article discusses naming constructions in Estonian dialects, which express what something, linguistically realized as an object argument, is called. The construction consists of a naming verb in the impersonal voice, an object, which is named somehow, and a complement, which expresses what the object is called (i.e., Something [OBJ] is called [V] something [COMPL]). All the three elements of the construction can vary in spoken dialect material, where the object argument and the complement can also be omitted in some cases. The goal of the article is to ascertain whether the variation in the naming constructions is influenced by dialectal differences or rather by intraconstructional factors, which in turn may be linked to the spoken form of communication.

The dataset, consisting of 905 naming constructions, was extracted from the Corpus of Estonian Dialects, annotated for verb, object, complement, the occurrence of the connector et 'that', and the dialect area, and analysed by using conditional inference trees (Breiman et al. 1984; Hothorn et al. 2006) and correspondence analysis (Greenacre $2006,2007)$. The combination of the two methods was chosen to reveal as many of the associations and interactions between the variables as possible.

The results showed that a surprising amount of the variation can be explained by the dialect area in which the construction is used. The lexical variation in the construction, i.e., the choice of the finite verb, displayed the clearest link to areal distribution: the southern dialects (Mulgi, Tartu, Võru, Seto) and the adjacent Eastern dialect showed a clear preference for the verb kutsuma 'to call; to invite', whereas the northern dialects 
preferred the verb hü̈̈dma 'to call; to shout'. The verb hõikama 'to call (out); to shout (out)' was almost exclusively used in the Mulgi dialect (spoken in southern Estonia), and the verb nimetama 'to call, to name; to mention' associated more with Alutaguse dialect (the dialect spoken in the north-easternmost part of Estonia, next to the Russian border). Not surprisingly, lexical variation is where the traditional division of Estonian dialects to northern and southern group applies.

The choice of the object argument marking was also primarily dialectally determined, but the dialects were divided rather on the eastern-western axis: the eastern dialects (Alutaguse, Coastal, Eastern, Võru, Seto) were more prone to mark the object in the translative case, which is also the canonical case for the object in the naming construction in standard written Estonian, whereas in the western dialects (Insular, Western, Mid, Mulgi) and in Tartu dialect, the most frequent case for object marking was the nominative. This is in accordance with previous studies on Estonian dialects (Lindström forthcoming), according to which in the western dialects the nominative tends to acquire the functions of the partitive case in the contexts where the opposition of the two cases is not semantically relevant. The omission of the object argument does not depend on the dialect area, but is rather connected with information structure and the universal principle, according to which the information that is known and/or can be predicted does not need to be explicitly expressed (Givón 2017: 3).

Complement marking does not show clear dialectal differences, but is instead affected by the choice of object argument marking. Although it is the nominative case that is, somewhat surprisingly, by far the most frequent option for complement marking in the dialect corpus data, the expected translative case is slightly more prominent, when the object is also marked as one would expect it to be in standard Estonian, i.e., in the partitive case. The abundant use of the nominative case can be explained by the specifics of spoken language, where the complement is typically used as a citation and is therefore less integrated to the verb's argument structure. Compared to the omission of the object argument, the omission of the complement was rare, which is not surprising: the complement entails new and therefore the most important information and omitting it is only possible in somewhat exceptional cases, such as self-repairs.

It is up to future research to determine whether or not the variation in the form of the naming constructions is also tied to additional factors not taken into account in this study. Such factors include word order (i.e., the position of the complement and the object in relation to the finite verb), and the principles of information structure, which might have an even greater effect also on the omission of the arguments. 